BNL- 27755

Informal Report

Limited Distribution

\title{
MASTER
}

\section{FUSION BLANKETS FOR HIGH EFFICIENCY POWER CYCLES}

\author{
J.R. POWELL, J.A. FILLO, F.L. HORN, \\ O.W. LAZARETH, J.L. USHER \\ DEPARTMENT OF NUCLEAR ENERGY
}

\section{APRIL 1980}

BROOKHAVEN NATIONAL LABORATORY

UPTON, NEW YORK 11973 


\section{DISCLAIMER}

This report was prepared as an account of work sponsored by an agency of the United States Government. Neither the United States Government nor any agency Thereof, nor any of their employees, makes any warranty, express or implied, or assumes any legal liability or responsibility for the accuracy, completeness, or usefulness of any information, apparatus, product, or process disclosed, or represents that its use would not infringe privately owned rights. Reference herein to any specific commercial product, process, or service by trade name, trademark, manufacturer, or otherwise does not necessarily constitute or imply its endorsement, recommendation, or favoring by the United States Government or any agency thereof. The views and opinions of authors expressed herein do not necessarily state or reflect those of the United States Government or any agency thereof. 


\section{DISCLAIMER}

Portions of this document may be illegible in electronic image products. Images are produced from the best available original document. 
BNL- 27755

Tnformal Report

Limited Distribution

FUSION BLANKETS FOR HIGH EFFICIENCY POWER CYCLES*

J.R. Powell, J.A. Fillo, F.L. Horn, O.W. Lazareth, J.L. Usher

April 1980

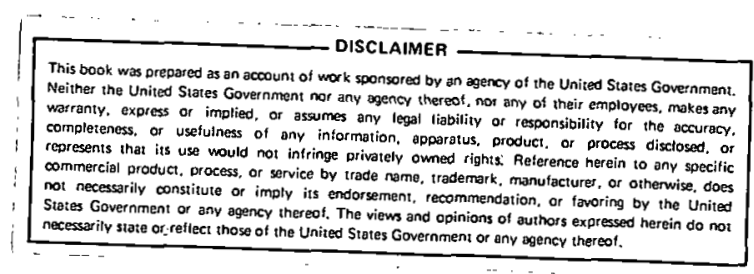

INFORMAL REPORT

\footnotetext{
*Work performed under the auspices of the Electric Power Research Institute, Palo Alto, CA.

B R O O K H A VEN N A T I ON A L L A B O R A T O R Y

A S S O C I A T E D U N I VER S I T I E S, I N C.

Under Contract No. DE-ACO2-76CH00016 with the

UNITED STATES DEPARTMENT OF ENERGY
} 


\section{NOT I C E}

"This report was prepared as an account of work sponsored by the United States Government. Neither the United States nor the United States Department of Energy, nor any of their employees, nor any of their contractors, subcontractors, or their employees, makes any warranty, express or implied, or assumes any legal liability or responsibility for the accuracy, completeness, or usefulness of any information, apparatus, product or process disclosed, or represents that its.use would not infringe privately owned rights." 
TABLE OF CONTENTS

Page

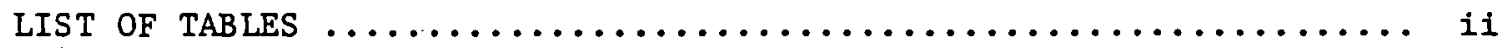

LIST OF FIGURES $\ldots \ldots \ldots \ldots \ldots \ldots \ldots \ldots \ldots \ldots \ldots \ldots \ldots \ldots \ldots \ldots \ldots \ldots \ldots \ldots \ldots \ldots$

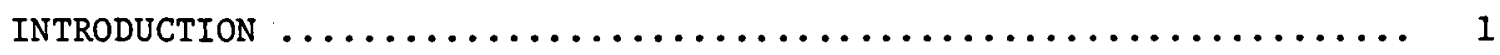

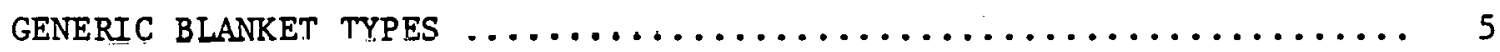

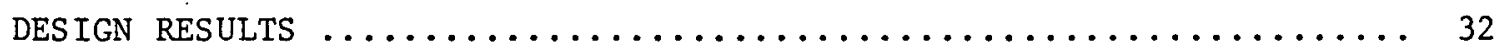

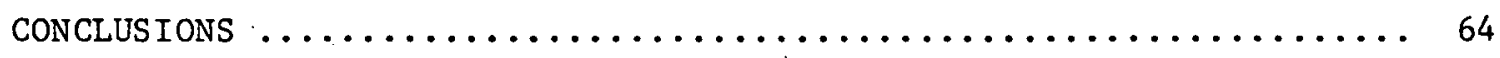

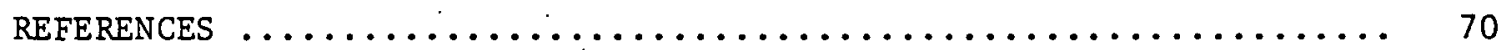


Table 1 Generic Fusion Blanket Types for High Efficiency

Power Cycles ............................. 6

Table 2. Blanket No. $1 \ldots \ldots \ldots \ldots \ldots \ldots \ldots \ldots \ldots \ldots \ldots \ldots$

Table $3 \quad$ Blanket No. $2 \ldots \ldots \ldots \ldots \ldots \ldots \ldots \ldots \ldots \ldots \ldots \ldots$

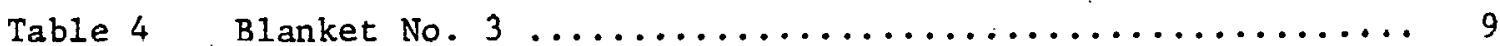

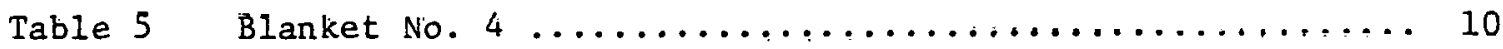

Table 6 Blanket No. $5 \ldots \ldots \ldots \ldots \ldots \ldots \ldots \ldots \ldots \ldots \ldots \ldots$

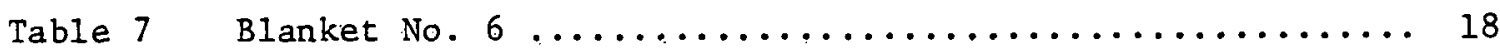

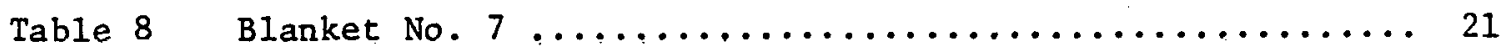

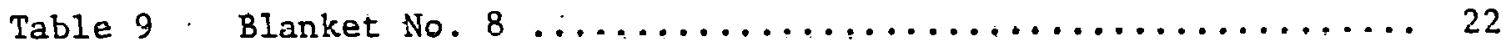

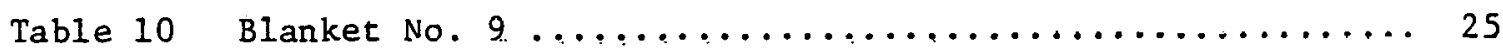

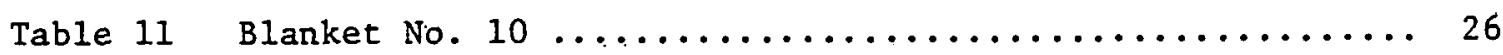

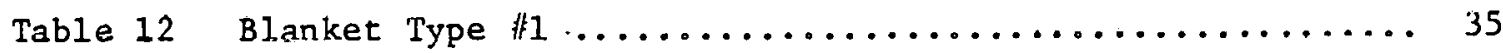

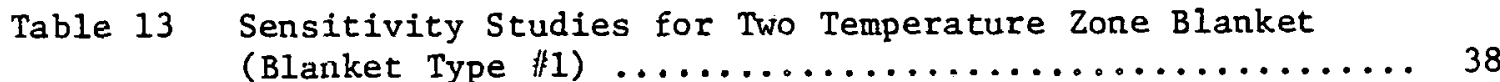

Table 14 Results of Sensitivity Studies for Two Temperature Blankets (Blanket Type $\|_{1}$ ) ........................... 39

Table 15 Blanket Type $\# 2 \ldots \ldots \ldots \ldots \ldots \ldots \ldots \ldots \ldots \ldots \ldots \ldots \ldots \ldots$

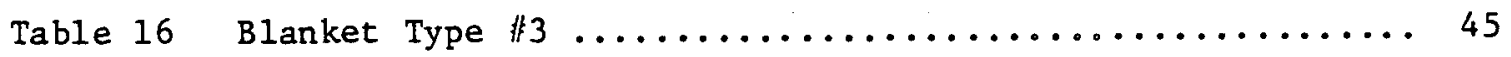

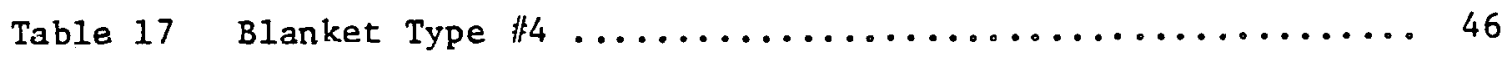

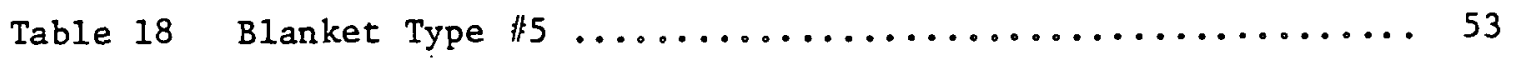

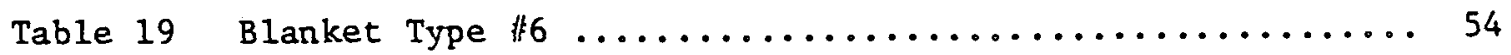


LIST OF TABLES, continued

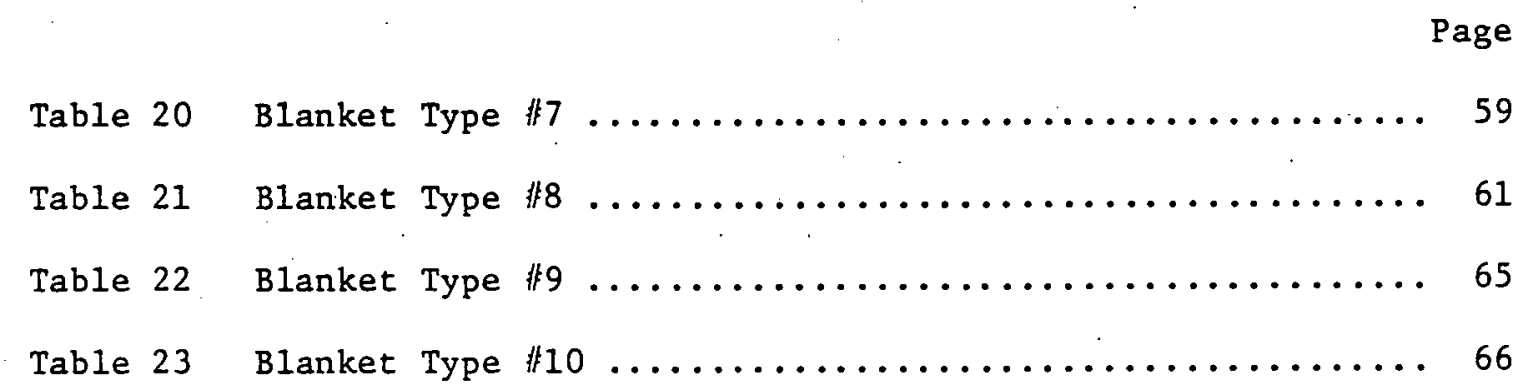


Figure 1 Generic Blanket Flow Sheet $\|_{1} 1 \ldots \ldots \ldots \ldots \ldots \ldots \ldots \ldots \ldots 12$

Figure 2 Generic Blanket Flow sheet $\# 2 \ldots \ldots \ldots \ldots \ldots \ldots \ldots \ldots$

Figure 3 Generic Blanket Flow sheet $\|_{3} 3 \ldots \ldots \ldots \ldots \ldots \ldots \ldots \ldots \ldots$

Figure 4 Generic Blanket Flow sheet $\$ 4 \ldots \ldots \ldots \ldots \ldots \ldots \ldots \ldots \ldots$

Figure 5 Generic Blanket Flow Sheet $\$ 5 \ldots \ldots \ldots \ldots \ldots \ldots \ldots \ldots \ldots$

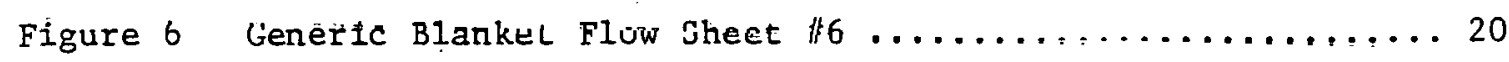

Figure 7 Generic Blanket Flow sheet $\# 7 \ldots \ldots \ldots \ldots \ldots \ldots \ldots \ldots \ldots$

Figure 8 Generic Blanket Flow Sheet $\sharp 8 \ldots \ldots \ldots \ldots \ldots \ldots \ldots \ldots$

Figure 9 Generic Blanket Flow Sheet $\# 9 \ldots \ldots \ldots \ldots \ldots \ldots \ldots \ldots \ldots$

Figure 10 Generic Blanket Flow Sheet $\| 10 \ldots \ldots \ldots \ldots \ldots \ldots \ldots \ldots$

Figure 11 Generic Blanket Flow Sheet $\# 11 \ldots \ldots \ldots \ldots \ldots \ldots \ldots \ldots$

Figure 12 Generic Blanket Flow Sheet $\|_{12} \ldots \ldots \ldots \ldots \ldots \ldots \ldots \ldots \ldots$

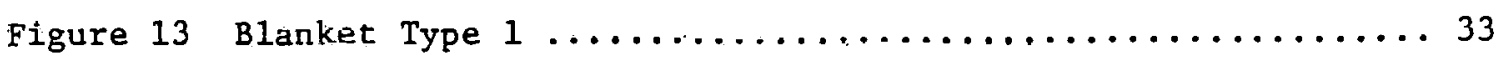

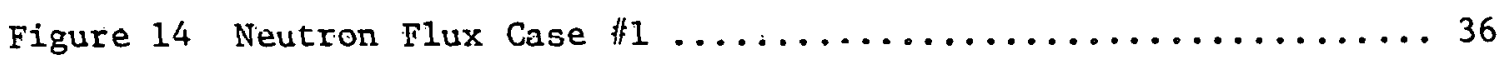

Figure 15 Heat Deposition Case $\|_{1} \ldots \ldots \ldots \ldots \ldots \ldots \ldots \ldots \ldots \ldots \ldots \ldots$

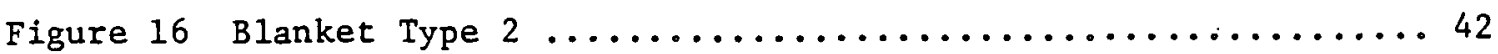

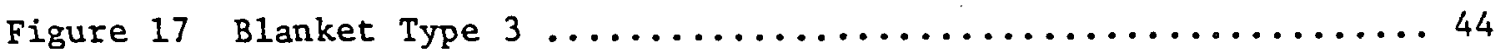

Figure 18 Neutron Flux Case $\$ 4 \ldots \ldots \ldots \ldots \ldots \ldots \ldots \ldots \ldots \ldots \ldots$

Figure 19 Heat Deposition Case $44 \ldots \ldots \ldots \ldots \ldots \ldots \ldots \ldots \ldots \ldots$

Figure 20 Case \#5, 1-Zone, He-Cooled, No Breeding ............ 50

Figure 21 Case $\# 5,1$-Zone, He-Cooled, No Breeding ............ 51 
LIST OF FIGURES, continued

Page

Figure 22 Case $\# 6,1$-Zone, He-Cooled, with Breeding $\ldots \ldots \ldots \ldots \ldots . \ldots 2$

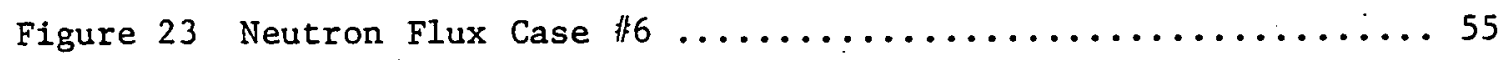

Figure 24 Blanket $\$ 7$ and $\# 8,2-$ Zone, K-Cooled (2 Phase) ........ 57

Figure 25 Blanket $\| 9$ and $\# 1 . n, 1$-Zone, K-Cooled (2 Phase) ......... 58

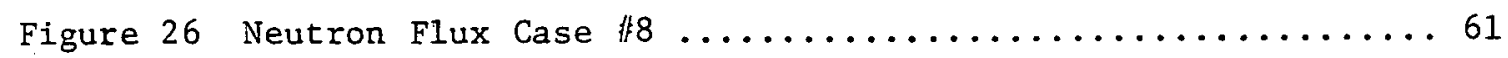

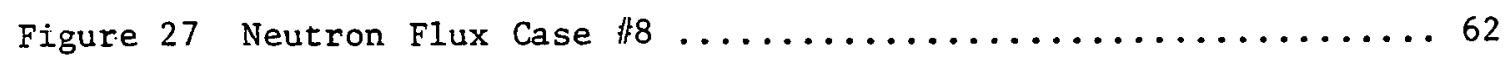

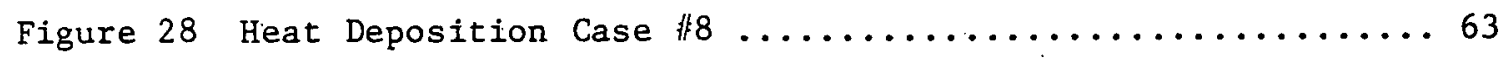

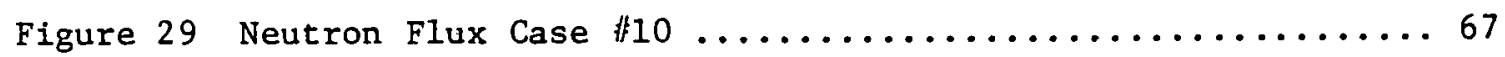


INTRODUCTION

To achieve high efficiency in a thermal power cycle, high coolant temperatures are necessary; in general, the higher the temperature available, the higher the efficiency of the cycle. The operating temperatures of conventional structural materials such as austenitic stainless or ferritic steels are limited to approximately $500^{\circ} \mathrm{C}$, which corresponds to a maximum cycle efficiency of about 40 percent. Coolant temperatures above $500^{\circ} \mathrm{C}$ are possible, however, using either of the following approaches:

1. A structural material with higher temperature capability can be used (e.g., a refractory metal like molybdenum (TZM) or niobium).

2. The blanket can be designed to be a "two temperature zone" blanket in which the structural material and first wall operate at a much lower temperature than the bulk of the blanket. The former approach requires either a liquid metal (or vapor) coolant or an inert gas coolant. Structural strength considerations limit the maximum temperature to $\sim 800$ to $1000^{\circ} \mathrm{C}$, depending on choice of coolant and blanket design. In the two temperature approach, first proposed by BNL ${ }^{(1)}$ for minimum activity blankets, the high energy (14 MeV) neutrons from the DT fusion reactions penetrate deeply and deposit their energy over the volume of the blanket, rather than on the first wall. If a thermally insultating layer is placed between the hot interior and the cooler structural shell of the blanket module, heat can be extracted at two different temperature levels by separate coolant streams for the interior and structural shell.

In general, the temperature available in the coolant from the hot interior will be limfted by the corrosion/erosion behavior of the interior material in the coolant and not by structural stress considerations. With inert gas coolants (e.g., He or A) and refractory interiors (e.g., graphite, oxides, or carbides), 
it appears possible to achieve coolant temperatures up to $2500^{\circ} \mathrm{C}$. With more reactive coolants (e.g., steam or potassium vapor) accompanied by the use of a refractory metal structure, maximum coolant temperatures will be somewhat lower, though they can still by very high. For example, materials experiments with steam coolant have been carried out at BNL as part of a development program on high temperature blankets for synfuel applications ${ }^{(2)}$, and indicate that snnlant temperatures of at least $1500^{\circ} \mathrm{C}$ are practical using either $\mathrm{ZrO}_{2}$ or $\mathrm{Al}_{2} \mathrm{O}_{3}$. In fact, higher operating temperatures may be possible with yttria stabillzed $\mathrm{ZrO}_{2}$, judging from tests on this material in high temperature wind Lumels. The mode of tritium breeding will also affect the temperature capability of two-zone blankets. The temperature capabilities discussed above assume that there is no tritium breeding in the hot interior of the blanket (though breeding could be carried out in the low temperature shell). If tritium breeding takes place in the hot interior, allowable coolant temperatures will be significantly reduced.

There appear to be two approaches to breeding tritlum in the hot interior-solid lithium compounds and liquid lithium in refractory metal tubes. In the first approach, high melting point solid lithium compounds (e.g., $\mathrm{Li}_{2} \mathrm{O}$ or $\mathrm{LiAlO}_{2}$ ) can be used in the module lulerior; tho bred trll lmiin would be released to the high temperature coolant stream, with subsequent recovery and recycle to the plasma. However, in order to ensure adequate tritium release capability, it is necessary to maintain small particle size in the solid lithium compound and to prevent sintering. Tests at $\mathrm{BNL}^{(3)}$ have investigated the tritium release characteristics of solid lithium compounds at elevated temperatures (up to $1000^{\circ} \mathrm{C}$ ) for extended periods of time (up to 3 months). $\mathrm{Li}_{2} \mathrm{O}$ and $\mathrm{LiAlO}_{2}$ appear suitable for use up to at least $1000^{\circ} \mathrm{C}$ and possibly higher. It is doubtful, however, 
that substantially higher operating temperatures can be achieved, since at $1000^{\circ} \mathrm{C}$ the materials are entering the range $\left(\sim 0.6\right.$ of $T_{m}$ ) where sintering effects become important.

Thus tritium breeding in the hot interior appears to limit maximum coolant temperatures to $\sim 1000^{\circ} \mathrm{C}$, assuming inert gas coolant. Tritium breeding with a reactive coolant such as steam is probably not feasible because of the chemical reaction between steam and solid lithium compounds and the difficulty of isotopically separating tritium from hydrogen in steam.

The two temperature zone blanket approach can be used with a hot interior of liquid lithium in refractory metal tubes (with a thermal insulator between the hot interior and the cooler metal shell). The interior would then be cooled either by an inert gas or potassium coolant. Tritium would be extracted either by circulating the lithium to an external processing unit or by releasing it to the coolant stream with subsequent trapping. Compatibility and structural considerations appear to limit manimum eoolant temperalures to about $1200^{\circ} \mathrm{C}$ with liquid lithium interiors, however.

There appears to be no problem in obtaining adequate tritium breeding for designs where tritium is bred in the hot interior of the blanket. If tritium breeding is confined to the cooler shell region, however, it appears difficult to achieve tritium self-sufficiency for the reactor unless a thick low temperature zone is used. This significantly reduces the fraction of energy available for the high temperature coolant stream.

If it is desired to maximize temperature capability while keeping the overall breeding ratio for the reactor equal to one, the best approach is probably to have two different types of blankets in the reactor. The first type, which would breed tritium in the interior, would have as high a breeding ratio 
as practical (on the order of 1.5 ), while maintaining the interior coolant at as high a temperature as possible $\left(\sim 1000\right.$ to $\left.1200^{\circ} \mathrm{C}\right)$. The second type, which would breed tritium only in the cooler shell region, would operate with a higher temperature interior (up to $\sim 2500^{\circ} \mathrm{C}$, depending on choice of coolant and the interfor material). Bried1ng ratlus up to $\sim 0.9$ to 1.0 appear practical for the second module type, so that only a relatively small fraction of the blanket would have to be devoted to the first module type.

Neutronic analyses of two temperature zone blankets indicate that 50 to bU percent of the cutal fugion cnorgy rolease (including alpha particle energy) san he deposited as high temperature heat in the interior of blanket modules. Essentially all of this energy can be extracted by the high temperalure coolant stream. BNL tests ${ }^{(4)}$ of a variety of thermal insulation materials $\left(\mathrm{ZrO}_{2}\right.$ felt, $\mathrm{ZrO}_{2}$ fibrous board, graphite felt, carbon felt, and alumina-silica mat) have been carried out as a function of temperature up to $1000^{\circ} \mathrm{C}$ in helium argon, and air atmospheres. Thermal conductivities of $\sim 0.1$ to 0.2 watts $/ \mathrm{m}^{\circ} \mathrm{K}$ are found at $1000^{\circ} \mathrm{C}$ in argon, and $\sim 0.4$ to 0.5 watts $/ \mathrm{m}^{\circ} \mathrm{K}$ in helium, with insulation thicknesses of 2 to $3 \mathrm{~cm}$ between the hot interior and the module shell; it thus appears possible to keep heat leakage between the two zones to only a few percent of that deposited in the interlor, for wall loadings on the order of $2 \mathrm{MW}(\mathrm{th}) / \mathrm{m}^{2}$.

It is the intent of this study to design a near-term reactor configuration, for this reason the reactor was sized to conform to typical TNS dimensions. As the reactor is to be near-term a low value of $Q(\approx 3.0)$ was assumed in the calculations. Also presumed was a nominal neutron wall $10 a d$ of $1.5 \mathrm{MW} / \mathrm{m}^{2}$. No divertor has been included in these design studies. A major radius of $5.0 \mathrm{~m}$ is utilized for the plasma which has a half-width of $1.2 \mathrm{~m}$ and is D-shaped with 
an elongation ratio of $1.6: 1.0$. The low value of $Q$ increases the importance of charged particle energy in these calculations and the fact that there is no divertor indicates that this charged-particle energy flux all impinges on the first wall. The small major radius will constrain the design somewhat in terms of inboard blanket and shield thickness.

The remainder of this report includes the definition of the 10 generic blanket types and the specific blanket chosen to be analyzed in detail from each of the 10 types. Dimensions, compositions, energy depositions and breeding ratios (where applicable) are presented for each of the 10 designs. U1timately, based largely on neutronics and thermal hydraulics results, breeding and nonbreeding blanket options are selected for further design analysis and integration with a suitable power conversion subsystem.

\section{GENERIC BLANKET TYPES}

Ten generic blanket types have heen investigated for potcntial use with high efficiency power cycles. Overall characteristics of these blankets are summarized in Table 1. Each type has a range of possible coolant and material options, half the blankets being tritium breeders and the other half non-breeders. The blankets are broken into three distinct groups. The first of these groups contains types 1-4; types 5 and 6 constitute the second group and the third group consists of types 7-10. The odd-numbered blanket types are non-breeders and generally have higher interior temperatures than do their even-numbered breeding counterparts.

The materials, coolants, temperatures and pressures envisioned for the first group of blankets are summarized in Tables 2-5. Blankets 1 and 2 both are two zone with a hot interior cooled by helium. (Argon was also considered initially as a possible interfor coolant). Interior and exterior materials and exterior 
TABLE 1

Genertc Fusion Blanket Types for High Effictency Power Cy:les

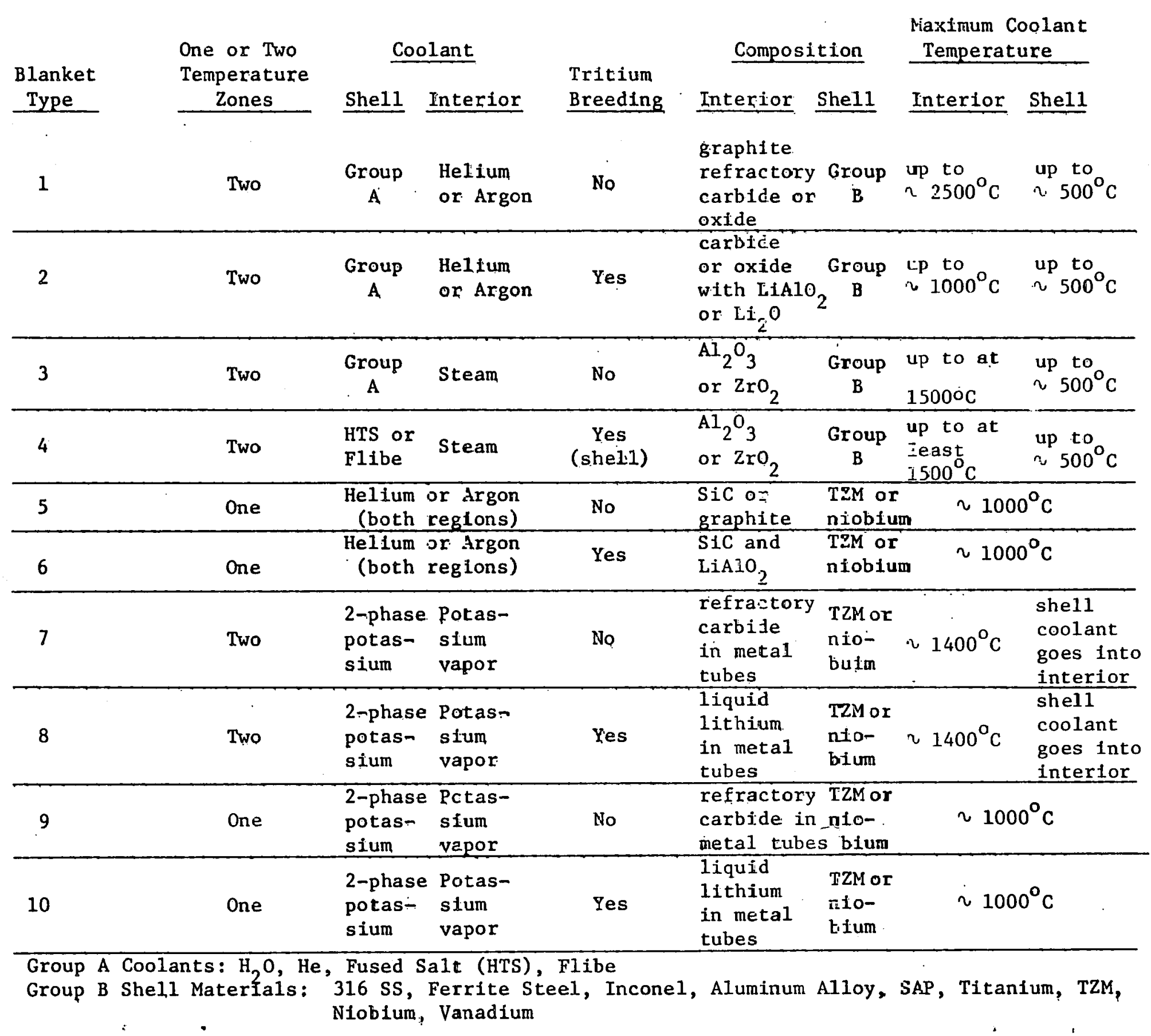


TABLE 2

BLANKET NO. 1 2-ZONE, He-COOLED

No BREEDING

\begin{tabular}{|c|c|c|c|c|c|c|c|}
\hline $\begin{array}{l}\text { Low Temp. } \\
\text { Structure }\end{array}$ & $\begin{array}{l}\text { Shell } \\
\text { Coolant }\end{array}$ & $\begin{array}{c}\mathrm{T}_{\max } \\
\text { Coolant } \\
\left({ }^{\circ} \mathrm{C}\right)\end{array}$ & $\begin{array}{c}\mathrm{P}_{\max } \\
\text { Coolant } \\
\text { (psi) }\end{array}$ & $\begin{array}{l}\Delta x_{\max } \\
\text { Shell } \\
\text { Module } \\
\text { (cm) }\end{array}$ & $\begin{array}{l}\text { Interior } \\
\text { Materials }\end{array}$ & $\begin{array}{c}\mathrm{T}_{\max } \\
\text { Coolant } \\
\left({ }^{\circ} \mathrm{C}\right)\end{array}$ & $\begin{array}{l}\mathrm{P}_{\text {max }} \\
\text { Coolant } \\
\text { (psi) }\end{array}$ \\
\hline $\begin{array}{l}* \quad 316 \\
\text { Stainless } \\
\text { Steel }\end{array}$ & $\begin{array}{l}\quad \mathrm{H}_{\mathrm{e}} \\
* \quad \mathrm{H}_{2} \mathrm{O} \\
\text { Fused }\end{array}$ & $\begin{array}{l}450 \\
300 \\
500\end{array}$ & $\begin{array}{r}900 \\
1500 \\
150\end{array}$ & $\begin{array}{l}1.0 \\
1.0 \\
1.0\end{array}$ & \multirow{6}{*}{ 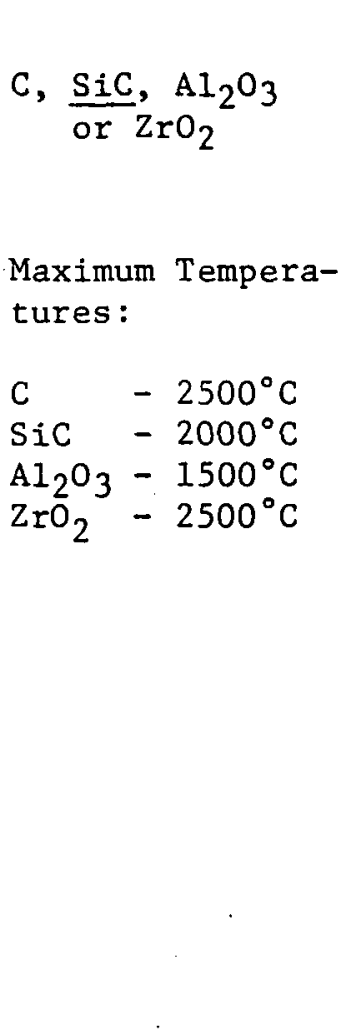 } & \multirow[t]{6}{*}{2000} & \multirow[t]{6}{*}{900} \\
\hline Inconel & $\begin{array}{c}\mathrm{He} \\
\mathrm{H}_{2} \mathrm{O} \\
\text { Fused } \mathrm{Salt}\end{array}$ & $\begin{array}{l}600 \\
300 \\
500\end{array}$ & $\begin{array}{r}900 \\
1500 \\
150\end{array}$ & $\begin{array}{l}1.0 \\
1.0 \\
1.0\end{array}$ & & & \\
\hline $\begin{array}{l}\text { Aluminum } \\
\text { alloy }\end{array}$ & $\begin{array}{l}\mathrm{He} \\
\mathrm{H}_{2} \mathrm{O}\end{array}$ & $\begin{array}{l}200 \\
200\end{array}$ & $\begin{array}{l}900 \\
500\end{array}$ & $\begin{array}{l}2.0 \\
2.0\end{array}$ & & & \\
\hline SAP & $\begin{array}{l}\mathrm{He} \\
\mathrm{II}_{2} \mathrm{O}\end{array}$ & $\begin{array}{l}350 \\
300\end{array}$ & $\begin{array}{r}900 \\
1500\end{array}$ & $\begin{array}{l}2.0 \\
2.0\end{array}$ & & & \\
\hline Titanium & $\begin{array}{c}\mathrm{He} \\
\mathrm{H}_{2} \mathrm{O} \\
\text { Fused Salt }\end{array}$ & $\begin{array}{l}500 \\
300 \\
400\end{array}$ & $\begin{array}{r}900 \\
1500 \\
150\end{array}$ & $\begin{array}{l}0.5 \\
0.5 \\
0.5\end{array}$ & & & \\
\hline $\mathrm{TZM}$ & $\mathrm{He}$ & 800 & 900 & 1.0 & & & \\
\hline
\end{tabular}


TABLE 3

BLANKET NO. 2 2-ZONE, He-COOLED

$T$ BREEDING

\begin{tabular}{|c|c|c|c|c|c|c|c|}
\hline $\begin{array}{l}\text { Luw Temp. } \\
\text { Structure }\end{array}$ & $\begin{array}{l}\text { Shell } \\
\text { Coolant }\end{array}$ & $\begin{array}{l}T_{\max } \\
\text { Coolant } \\
\left({ }^{\circ} \mathrm{C}\right)\end{array}$ & $\begin{array}{l}\mathrm{p}_{\max } \\
\text { Coolant } \\
\text { (psi) }\end{array}$ & $\begin{array}{l}\Delta \mathrm{x}_{\max } \\
\text { Shell } \\
\text { Module } \\
\text { (cm) }\end{array}$ & $\begin{array}{l}\text { Interior } \\
\text { Materials }\end{array}$ & $\begin{array}{l}\mathrm{T}_{\text {max }} \\
\text { Cinnlant } \\
\left({ }^{\circ} \mathrm{C}\right)\end{array}$ & $\begin{array}{l}P_{\max } \\
\text { Coolant } \\
\text { (psi) }\end{array}$ \\
\hline $\begin{array}{c}316 \\
\text { Stainless } \\
\text { Steel }\end{array}$ & $\begin{array}{c}\mathrm{He} \\
+\quad \mathrm{H}_{2} \mathrm{O} \\
\text { Fused Salt }\end{array}$ & $\begin{array}{l}450 \\
300 \\
500\end{array}$ & $\begin{array}{r}900 \\
1500 \\
150\end{array}$ & $\begin{array}{l}1.0 \\
1.0 \\
1.0\end{array}$ & $\begin{array}{l}\text { Ren with } \mathrm{LiAlO}_{2} \\
\text { with } \mathrm{C} \text {, } \mathrm{SiC} \text {, } \\
\mathrm{Al}_{2} \mathrm{O}_{3} \text { or } \mathrm{ZrO}{ }_{2}\end{array}$ & \multirow[t]{6}{*}{1000} & \multirow[t]{6}{*}{900} \\
\hline Incone1 & $\begin{array}{l}\mathrm{He} \\
\stackrel{\mathrm{H}_{2}}{ } \cap \\
\text { Fused Salt }\end{array}$ & $\begin{array}{l}600 \\
300 \\
500\end{array}$ & $\begin{array}{r}900 \\
1500 \\
150\end{array}$ & $\begin{array}{l}1.0 \\
1.0 \\
1.0\end{array}$ & \multirow{5}{*}{$\begin{array}{l}\text { Maximum Tempera- } \\
\text { tures: } \\
\mathrm{C}-1000^{\circ} \mathrm{C} \\
\mathrm{SiC}-1000^{\circ} \mathrm{C} \\
\mathrm{Al}_{2} \mathrm{O}_{3}-1100^{\circ} \mathrm{C} \\
\mathrm{ZrO}_{2}-1100^{\circ} \mathrm{C}\end{array}$} & & \\
\hline $\begin{array}{l}\text { Aluminum } \\
\text { alloy }\end{array}$ & $\begin{array}{l}\mathrm{He} \\
\mathrm{H}_{2} \mathrm{O}\end{array}$ & $\begin{array}{l}200 \\
200\end{array}$ & $\begin{array}{l}900 \\
500\end{array}$ & $\begin{array}{l}2.0 \\
2.0\end{array}$ & & & \\
\hline SAP & $\begin{array}{l}\mathrm{He} \\
\mathrm{H}_{2} \mathrm{O}\end{array}$ & $\begin{array}{l}350 \\
300\end{array}$ & $\begin{array}{r}900 \\
1500\end{array}$ & $\begin{array}{l}2.0 \\
2.0\end{array}$ & & & \\
\hline Titanium & $\begin{array}{c}\mathrm{He} \\
\mathrm{H}_{2} \mathrm{O} \\
\text { Fused Salt }\end{array}$ & $\begin{array}{l}500 \\
300 \\
400\end{array}$ & $\begin{array}{r}900 \\
1500 \\
150\end{array}$ & $\begin{array}{l}0.5 \\
0.5 \\
0.5\end{array}$ & & & \\
\hline TZM & $\mathrm{He}$ & 800 & 900 & 1.0 & & & \\
\hline
\end{tabular}


TABLE 4

BLANKET NO. 3 2-ZONE, $\mathrm{H}_{2} \mathrm{O}$-COOLED

No BREEDING

\begin{tabular}{|c|c|c|c|c|c|c|c|}
\hline $\begin{array}{l}\text { Low Temp. } \\
\text { Structure }\end{array}$ & $\begin{array}{l}\text { Shell } \\
\text { Coolant }\end{array}$ & $\begin{array}{c}\mathrm{T}_{\max } \\
\text { Coolant } \\
\left({ }^{\circ} \mathrm{C}\right)\end{array}$ & $\begin{array}{c}P_{\max } \\
\text { Coolant } \\
\text { (psi) }\end{array}$ & $\begin{array}{l}\Delta \mathrm{x}_{\max } \\
\text { Shell } \\
\text { Module } \\
\text { (cm) }\end{array}$ & $\begin{array}{l}\text { Interior } \\
\text { Materials }\end{array}$ & $\begin{array}{l}T_{\max } \\
\text { Coolant } \\
\left({ }^{\circ} \mathrm{C}\right)\end{array}$ & $\begin{array}{c}P_{\max } \\
\text { Coolant } \\
(p s i)\end{array}$ \\
\hline $\begin{array}{l}* \quad 316 \\
\text { Stainless } \\
\quad \text { Steel }\end{array}$ & \begin{tabular}{l}
\multicolumn{1}{c}{$\mathrm{He}$} \\
$* \quad \mathrm{H}_{2} \mathrm{O}$ \\
Fused
\end{tabular} & $\begin{array}{l}450 \\
300 \\
500\end{array}$ & $\begin{array}{r}900 \\
1500 \\
150\end{array}$ & $\begin{array}{l}1.0 \\
1.0 \\
1.0\end{array}$ & \multirow{6}{*}{ 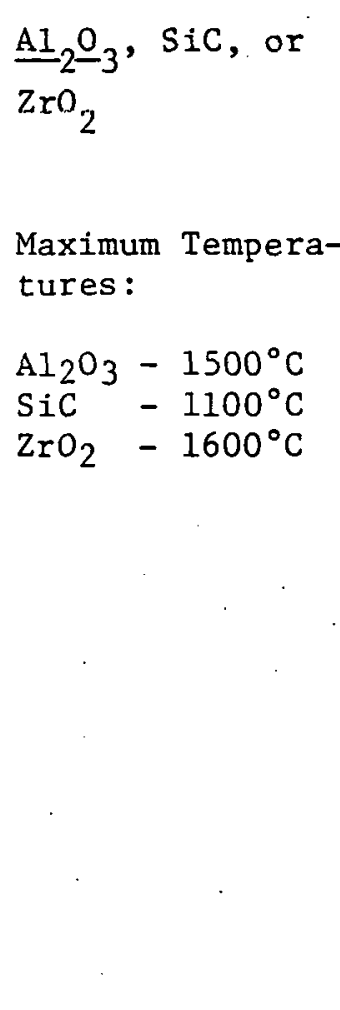 } & \multirow[t]{6}{*}{1500} & \multirow{6}{*}{ 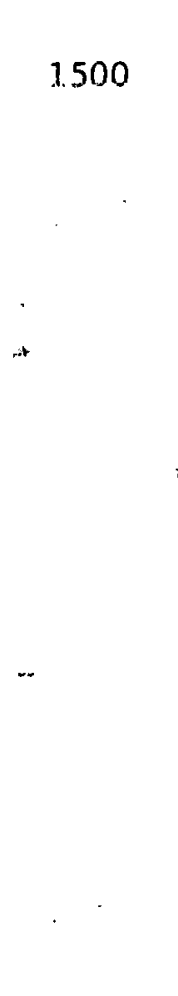 } \\
\hline Inconel & $\begin{array}{c}\mathrm{He} \\
\mathrm{H}_{2} \mathrm{O} \\
\text { Fused Salt }\end{array}$ & $\begin{array}{l}600 \\
300 \\
500\end{array}$ & $\begin{array}{r}900 \\
1500 \\
150\end{array}$ & $\begin{array}{l}1.0 \\
1.0 \\
1.0\end{array}$ & & & \\
\hline $\begin{array}{l}\text { Aluminum } \\
\text { alloy }\end{array}$ & $\begin{array}{l}\mathrm{He} \\
\mathrm{H}_{2} \mathrm{O}\end{array}$ & $\begin{array}{l}200 \\
200\end{array}$ & $\begin{array}{l}900 \\
500\end{array}$ & $\begin{array}{l}2.0 \\
2.0\end{array}$ & & & \\
\hline SAP & $\begin{array}{l}\mathrm{He} \\
\mathrm{H}_{2} \mathrm{O}\end{array}$ & $\begin{array}{l}350 \\
300\end{array}$ & $\begin{array}{r}900 \\
1500\end{array}$ & $\begin{array}{l}2.0 \\
2.0\end{array}$ & & & \\
\hline Titanium & $\begin{array}{c}\mathrm{He} \\
\mathrm{H}_{2} \mathrm{O} \\
\text { Fused Salt }\end{array}$ & $\begin{array}{l}500 \\
300 \\
400\end{array}$ & $\begin{array}{r}900 \\
1500 \\
150\end{array}$ & $\begin{array}{l}0.5 \\
0.5 \\
0.5\end{array}$ & & & \\
\hline TZM & $\mathrm{He}$ & 800 & 900 & 1.0 & & & \\
\hline
\end{tabular}


TABLE 5

BLANKET NO. 4 2-ZONE, $\mathrm{H}_{2}$ O-COOLED

T BREEDING

\begin{tabular}{|c|c|c|c|c|c|c|c|}
\hline $\begin{array}{l}\text { Low Temp. } \\
\text { Structure }\end{array}$ & $\begin{array}{l}\text { Shell } \\
\text { Coolant }\end{array}$ & $\begin{array}{l}T_{\max } \\
\text { Coolant } \\
\left({ }^{\circ} \mathrm{C}\right)\end{array}$ & $\begin{array}{l}\mathrm{P}_{\max } \\
\text { Coolant } \\
(p s i)\end{array}$ & $\begin{array}{l}\Delta x_{\text {max }} \\
\text { Shell } \\
\text { Module } \\
\text { (cm) }\end{array}$ & $\begin{array}{l}\text { Interior } \\
\text { Materials }\end{array}$ & $\begin{array}{l}T_{\max } \\
\text { Coolant } \\
\left({ }^{\circ} \mathrm{C}\right)\end{array}$ & $\begin{array}{l}\mathbf{P}_{\max } \\
\text { Coolant } \\
(p s i)\end{array}$ \\
\hline $\begin{array}{l}* \quad 316^{*} \\
\text { Stainless } \\
\text { Steel }\end{array}$ & $\begin{array}{l}\mathrm{He} \\
* \quad \mathrm{H}_{2} \mathrm{O} \\
\text { Fused Salt }\end{array}$ & $\begin{array}{l}450 \\
300 \\
500\end{array}$ & $\begin{array}{r}900 \\
1500 \\
150\end{array}$ & $\begin{array}{l}1.0 \\
1.0 \\
1.0\end{array}$ & $\begin{array}{l}\text { BeO and } \mathrm{LiAlO}_{2} \\
\text { with } \mathrm{Al}_{2} \mathrm{O}_{3} \\
\underline{\mathrm{SiC}}, \text { or } \mathrm{ZrO}_{2}\end{array}$ & 1000 & 150 \\
\hline Incunel & $\begin{array}{l}\mathrm{He} \\
\mathrm{H}_{2} \mathrm{O} \\
\text { Fused Salt }\end{array}$ & $\begin{array}{l}600 \\
300 \\
500\end{array}$ & $\begin{array}{r}900 \\
1500 \\
150\end{array}$ & $\begin{array}{l}1.0 \\
1.0 \\
1.0\end{array}$ & $\begin{array}{l}\text { Maximum tempera } \\
\text { tures: } \\
\mathrm{Al}_{2} \mathrm{O}_{3}-1100^{\circ} \mathrm{C}\end{array}$ & . & \\
\hline $\begin{array}{l}\text { Aluminum } \\
\text { alloy }\end{array}$ & $\begin{array}{l}\mathrm{He} \\
\mathrm{H}_{2} \mathrm{O}\end{array}$ & $\begin{array}{l}200 \\
200\end{array}$ & $\begin{array}{l}900 \\
500\end{array}$ & $\begin{array}{l}2.0 \\
2.0\end{array}$ & $\begin{array}{l}\mathrm{SiC}-1100^{\circ} \mathrm{C} \\
\mathrm{ZrO}_{2}-1100^{\circ} \mathrm{C}\end{array}$ & & \\
\hline SAP & $\mathrm{He}$ & $\begin{array}{l}350 \\
300\end{array}$ & $\begin{array}{r}900 \\
1500\end{array}$ & $\begin{array}{l}2.0 \\
2.0\end{array}$ & & & \\
\hline Titanium & $\begin{array}{l}\mathrm{He} \\
\mathrm{H}_{2} \mathrm{O} \\
\text { Fused Sa 1,t }\end{array}$ & $\begin{array}{l}500 \\
300 \\
400\end{array}$ & $\begin{array}{r}900 \\
1500 \\
150\end{array}$ & $\begin{array}{l}0.5 \\
0.5 \\
0.5\end{array}$ & & & \\
\hline TZM & $\mathrm{He}$ & 800 & 900 & 1.0 & & & \\
\hline
\end{tabular}


coolant options are identified and corresponding maximum operating temperatures and pressures are delineated in Tables 2 and 3 . After surveying the potential material and coolant combinations, a most favorable set of combinations was chosen for detailed neutronic and thermal hydraulic analysis for each of the blanket types. This most favorable set of options is indicated by asterisks and underlining on Tables 2 and 3. For blanket type 1 (the non-breeder) a 316 stainless steel water-cooled exterior is chosen and a helium-cooled SiC interior is selected. It is estimated that the maximum interior temperature may be $2000^{\circ} \mathrm{C}$. For breeding blanket type 2 once again the water-cooled 316 stainless steel exterior is chosen with $\mathrm{SiC}$ being the major interior material choice. For breeding purposes $\mathrm{LiAlO}_{2}$ is chosen and $\mathrm{BeO}$ is utilized as a neutron multiplier. Aiding in the selection of the material and coolant combinations were overall power cycle considerations depicted in Figures 1 and 2 . In fact, blanket flow sheets were constructed for each of the ten blanket types prior to any narrowing of the material and coolant options.

Tables 4 and 5 present the materials and coolant options for blanket types 3 and 4. The options are similar to types 1 and 2 except that in these cases the hot interior is cooled by high temperature steam. Figures 3 and 4 illustrate the overall power cycle for these two blanket types. As in the case of the previous blankets, a material/coolant combination is selected for each blanket type to be analyzed in greater detail. For blanket type 3 water-cooled 316 stainless steel is chosen for the exterior structure and $\mathrm{Al}_{2} \mathrm{O}_{3}$ is chosen for the hot interior. A maximum coolant temperature of $1500^{\circ} \mathrm{C}$ is envisioned in the hot interior. For the breeding blanket type 4, stainless steel with steam coolant is chosen for the exterior structure with SiC selected for the hot interior. $\mathrm{LiAlO}_{2}$ is utilized as breeding material with a BeO neutron multiplier, and breeding requirements necessitate a maximum temperature of $1000^{\circ} \mathrm{C}$ in the hot interior. 


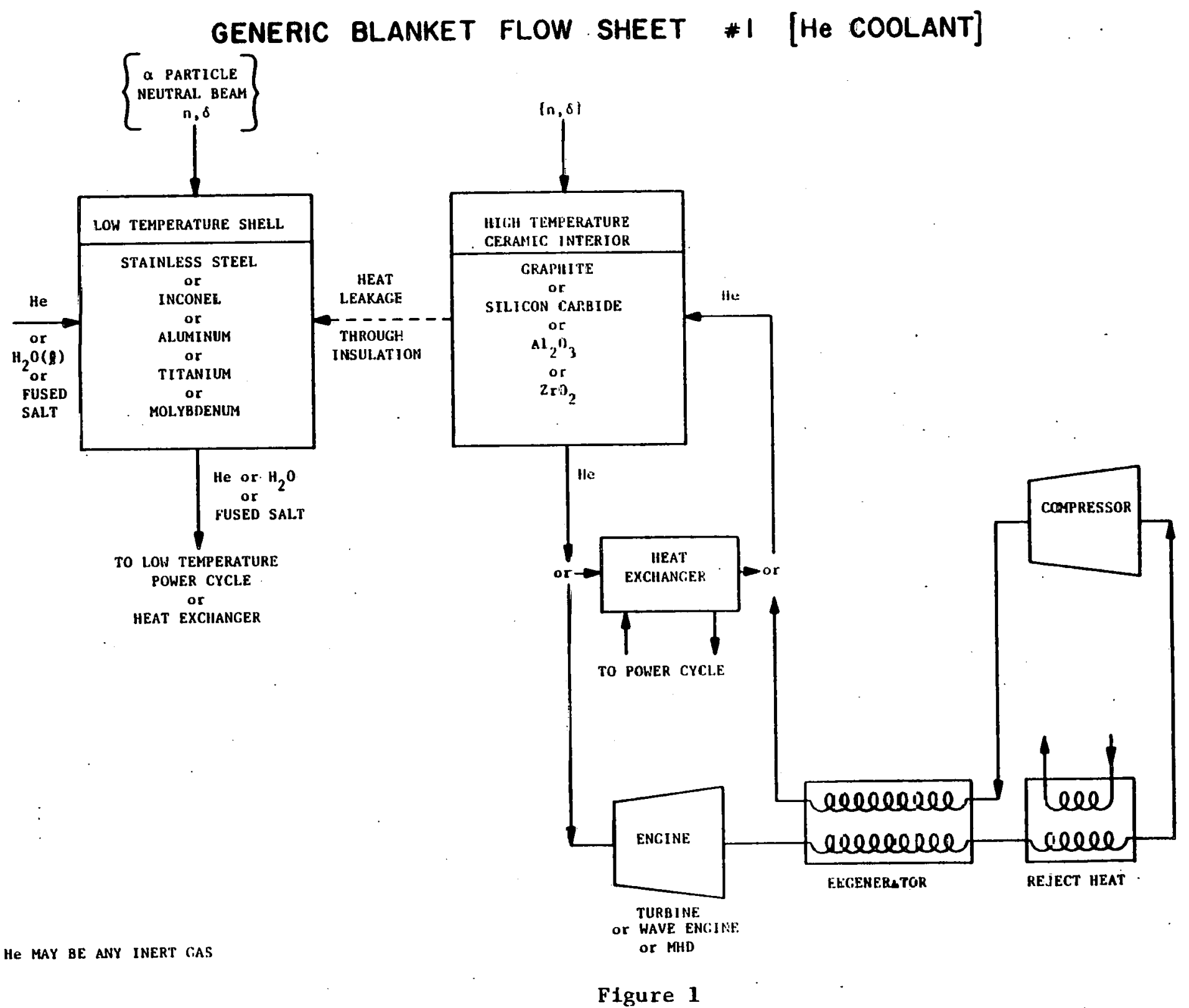




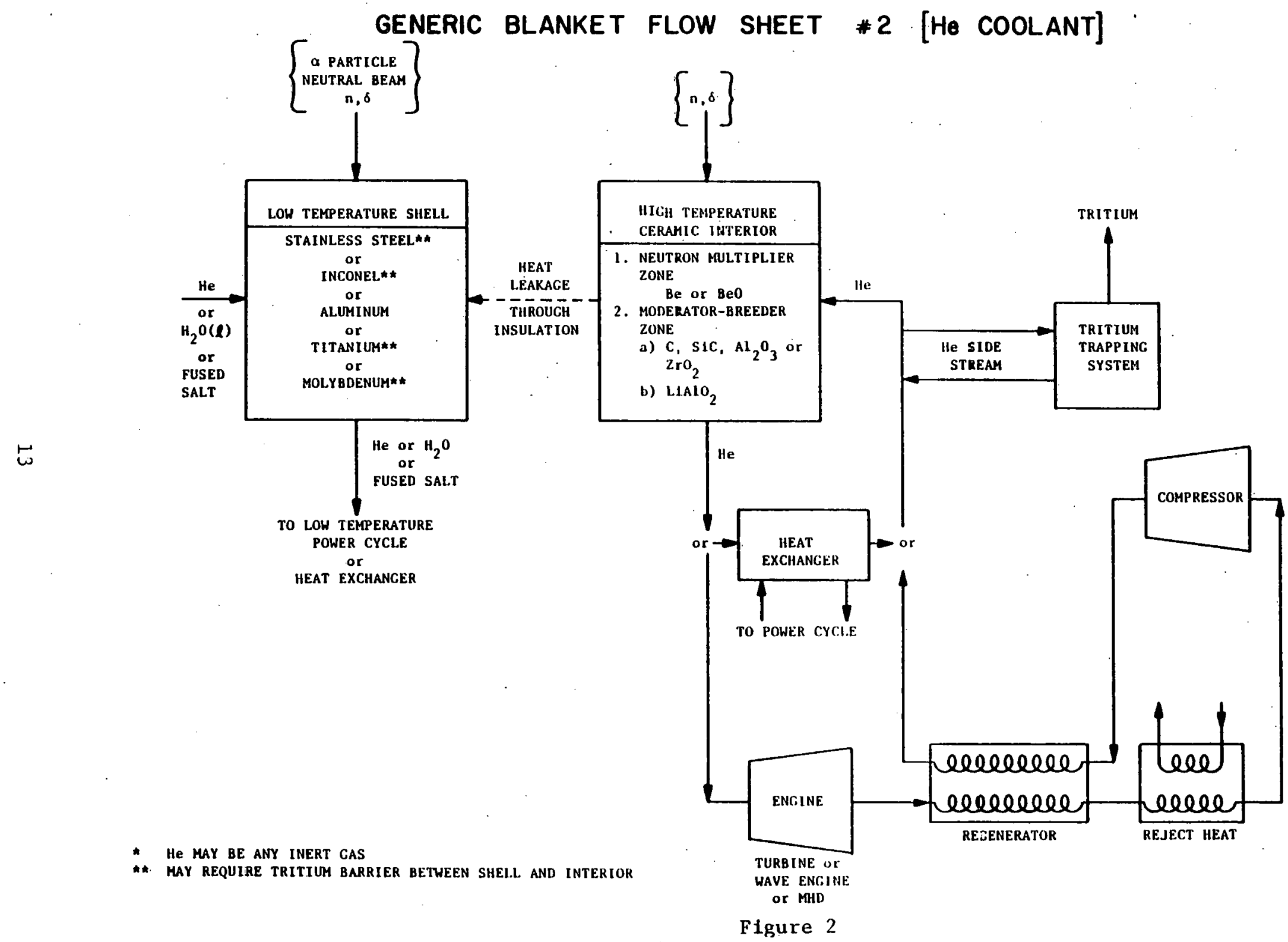




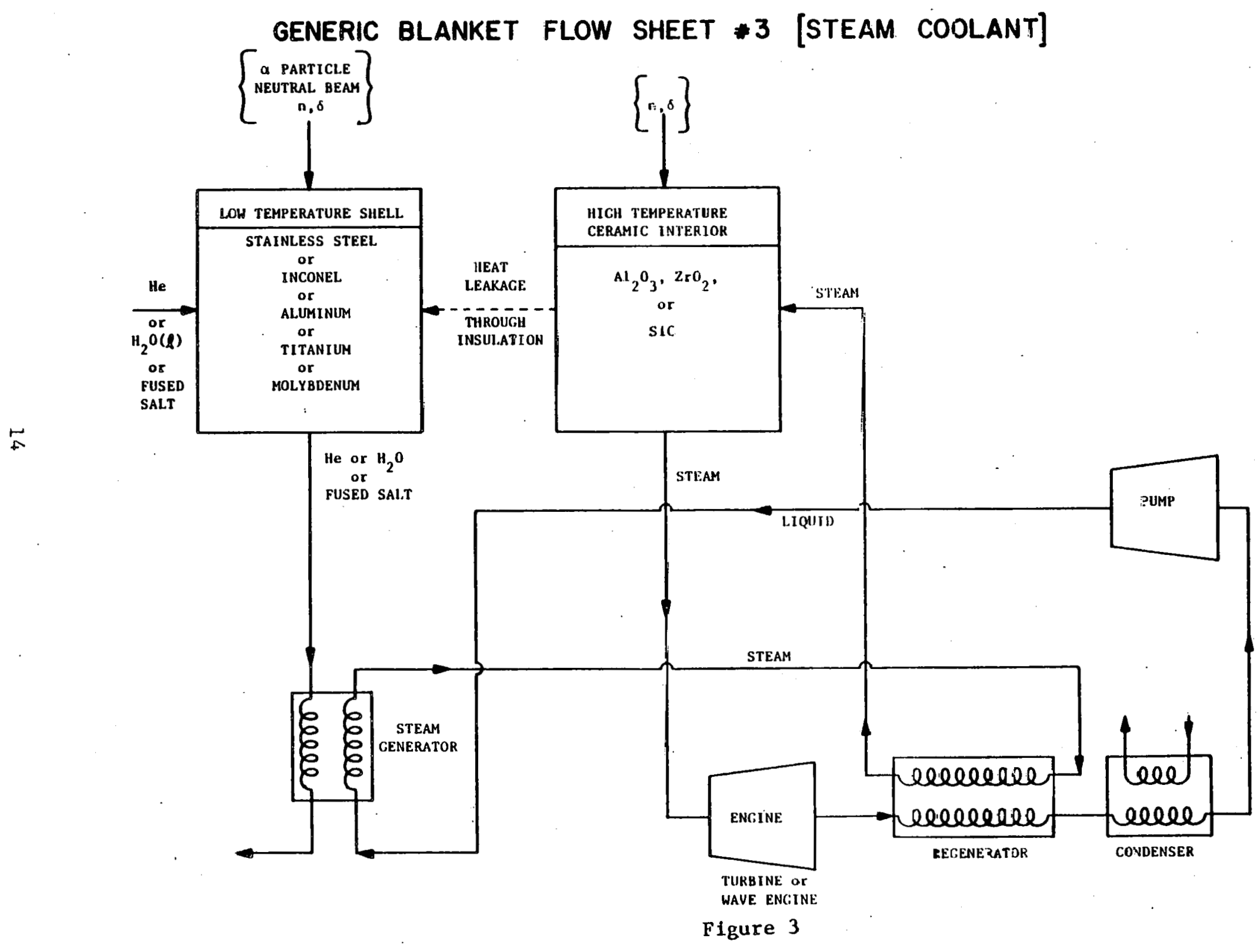




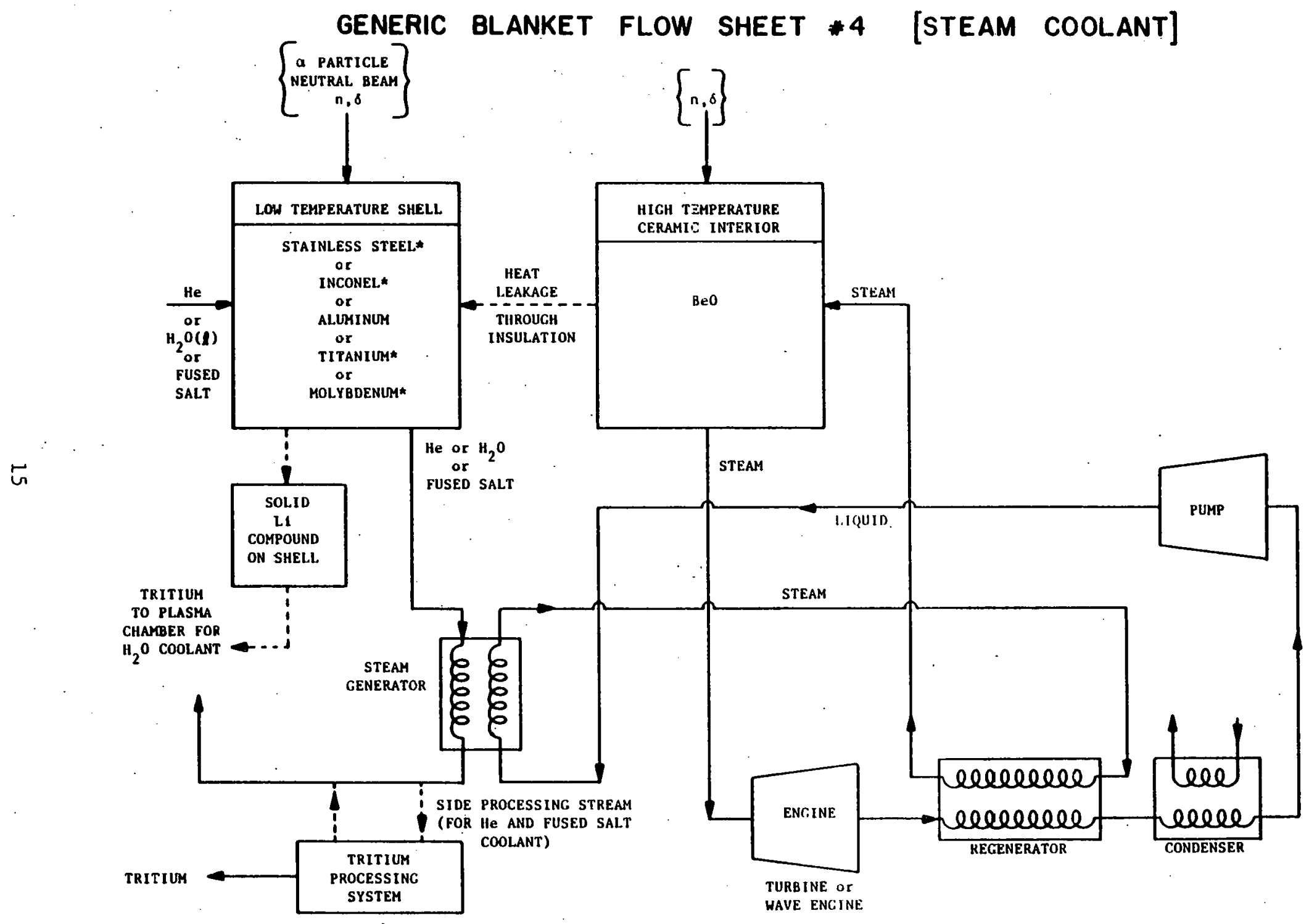

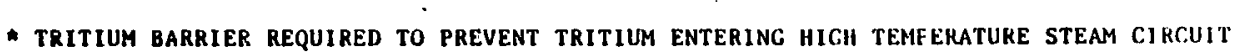

Figure 4 
The second group of blankets is composed of types 5 and 6 . These are one zone helium cooled blankets with material options summarized in Tables 6 and 7. The fact that these blankets are one zone simplifies the power cycle processes illustrated in Figures 5 and 6. For blanket type 5 TZM (an alloy primarily composed of molybdenum) is chosen as the exterior structural material and Sic is selected for the hot interior. Maximum coolant temperatures of $1000^{\circ} \mathrm{C}$ are desirable. Breeding blanket type 6 again has a TZM exterior and a SiC interior. $\mathrm{LiAlO}_{2}$ is used as breeding material Be Included as a neutron multiplier. Maximum coolant temperature is again expected to be $1000^{\circ} \mathrm{C}$.

The final group of blanket types are depicted in Tables $8-11$. These blankets utilize a two-phase mixture of potassium as exterior coolant and potassium vapor to cool the hot interior. Blanket types 7 and 8 are two-zone blankets. Material options are summarized in Tables 8 and 9 . The power cycle elements are depicted in Figures 7 and 8 for these two blanket types. Particular material options which have been selected for further analysis are indicated in Tables 8 and 9. For blanket type 7 TZM is selected as the exterior material and the two-phase coolant is anticipated to have a maximum temperature of $1200^{\circ} \mathrm{C}$. The interior will conslst of 2IC canned in TZM and will be cooled by potassium vapor with a maximum temperature of $1400^{\circ} \mathrm{C}$, Breeding blanket type 8 has an exterior composed of TZM and the interfor consists of FLIBE canned in TZM. Both interior and exterior maximum coolant temperatures are expected to be $1200^{\circ} \mathrm{C}$.

Blanket types 9 and 10 are one-zone, two-phase potassium cooled blankets. The material options are presented in Tables 10 and 11 . Since the blankets are one zone, simplified power cycle elements are necessitated; these are shown in Figures 9 and 10. For blanket type 9 TZM is chosen as structural materials; ZrC is canned in TZM in the blanket interior. For the breeding blanket type 10, TZM is again utilized with FLIBE canned in TZM used as breeding material. Blankets 9 and 10 both have desired maximum coolant temperatures of $1200^{\circ} \mathrm{C}$. 
TABLE 6

BLANKET NO. 5 1-ZONE, He-COOLED

No BREEDING

\begin{tabular}{|c|c|c|c|c|c|c|c|}
\hline $\begin{array}{l}\text { Low Temp. } \\
\text { Structure }\end{array}$ & $\begin{array}{l}\text { Shell } \\
\text { Coolant }\end{array}$ & $\begin{array}{l}T_{\text {max }} \\
\text { Coolant } \\
\left({ }^{\circ} \mathrm{C}\right)\end{array}$ & $\begin{array}{l}P_{\max } \\
\text { Coolant } \\
\text { (psi) }\end{array}$ & $\begin{array}{l}\Delta x_{\max } \\
\text { Shell } \\
\text { Module } \\
\text { (cm) }\end{array}$ & $\begin{array}{l}\text { Interior } \\
\text { Materials }\end{array}$ & $\begin{array}{l}T_{\max } \\
\text { Coolant } \\
\left({ }^{\circ} \mathrm{C}\right)\end{array}$ & $\begin{array}{l}P_{\text {max }} \\
\text { Coolant } \\
\text { (psi) }\end{array}$ \\
\hline SiC & $\mathrm{He}$ & 1400 & 900 & -- & Sic tubes & 1400 & 900 \\
\hline * TZM & $\mathrm{He}$ & 1000 & 900 & 0.5 & $\frac{\mathrm{SiC}}{\text { or }} \mathrm{ZrO}_{2} \mathrm{C}, \mathrm{Al}_{2} \mathrm{O}_{3}$, & 1000 & 900 \\
\hline
\end{tabular}


TABLE 7

BLANKET NO. 6 1-ZONE, He-COOLED

T BREEDING

\begin{tabular}{|c|c|c|c|c|c|c|c|}
\hline $\begin{array}{l}\text { Low Temp. } \\
\text { Structure }\end{array}$ & $\begin{array}{l}\text { Shell } \\
\text { Coolant }\end{array}$ & $\begin{array}{l}T_{\max } \\
\text { Coolant } \\
\left({ }^{\circ} \mathrm{C}\right)\end{array}$ & $\begin{array}{l}P_{\max } \\
\text { Coolant } \\
\text { (psi) }\end{array}$ & $\begin{array}{l}\Delta x_{\max } \\
\text { Shell } \\
\text { Module } \\
(\mathrm{cm})\end{array}$ & $\begin{array}{l}\text { Interior } \\
\text { Materials }\end{array}$ & $\begin{array}{l}T_{\text {max }} \\
\text { Coolant } \\
\left({ }^{\circ} \mathrm{C}\right)\end{array}$ & $\begin{array}{l}P_{\max } \\
\text { Coolant } \\
\text { (psi) }\end{array}$ \\
\hline SiC & He & 1000 & 900 & -- & $\begin{array}{l}\mathrm{Be}, \mathrm{BeO} \text {, and } \\
\mathrm{LiAlO}_{2} \text { in } \mathrm{SiC} \\
\text { tulies }\end{array}$ & 1000 & 900 \\
\hline$*$ TZM & $\mathrm{He}$ & 1000 & 900 & 0.5 & $\begin{array}{l}\mathrm{Be} \text { and } \mathrm{IiAlO}_{2} \\
\text { with } \mathrm{SiC}, \mathrm{C}, \\
\mathrm{Al}_{2} \mathrm{O}_{3} \text {, or } \mathrm{ZrO}_{2}\end{array}$ & 1000 & 900 \\
\hline
\end{tabular}




\section{GENERIC BLANKET FLOW SHEET *5 [He COOLANT]}

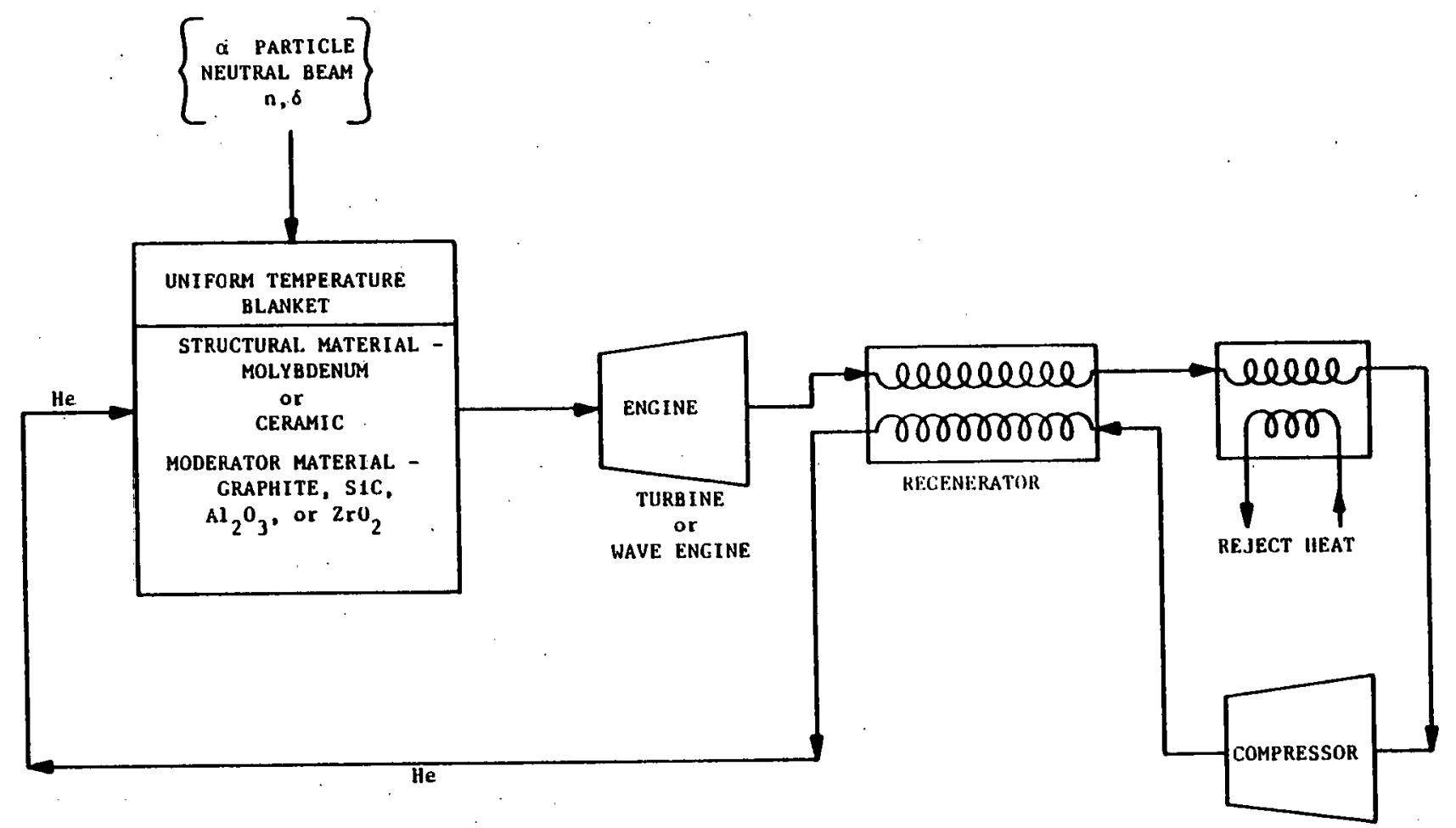

* He coolant may be any inert gas

Figure 5 


\section{GENERIC BLANKET FLOW SHEET *6 [He COOLANT]}

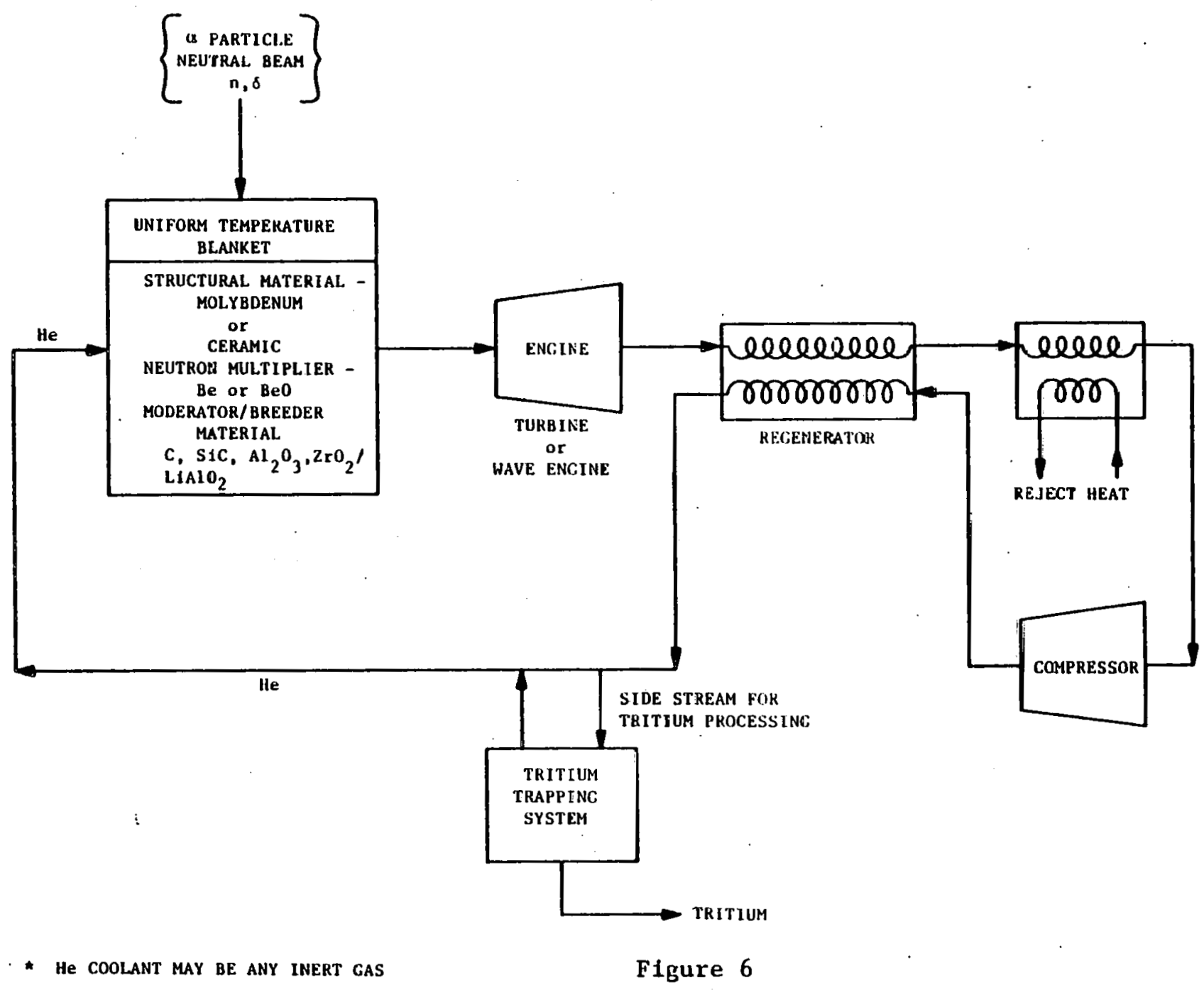


TABLE 8

BLANKET NO. 7 2-ZONE, K-COOLED

No BREEDING

\begin{tabular}{|c|c|c|c|c|c|c|c|}
\hline $\begin{array}{l}\text { Low Temp. } \\
\text { Structure }\end{array}$ & $\begin{array}{l}\text { Shell } \\
\text { Coolant }\end{array}$ & $\begin{array}{l}\mathrm{T}_{\max } \\
\text { Coolant } \\
\left({ }^{\circ} \mathrm{C}\right)\end{array}$ & $\begin{array}{l}P_{\text {max }} \\
\text { Coolant } \\
\text { (psi) }\end{array}$ & $\begin{array}{l}\Delta x_{\max } \\
\text { Shell } \\
\text { Module } \\
\text { (cIn) }\end{array}$ & $\begin{array}{l}\text { Interior } \\
\text { Materials }\end{array}$ & $\begin{array}{c}T_{\max } \\
\text { Coolant } \\
\left({ }^{\circ} \mathrm{C}\right)\end{array}$ & $\begin{array}{c}P_{\max } \\
\text { Coolant } \\
(p s i)\end{array}$ \\
\hline Niobium & $\mathrm{K}(1)$ & 1200 & 150 & 1.0 & $\begin{array}{l}\text { ZrC canned in } \\
\text { shell material }\end{array}$ & 1400 & 150 \\
\hline $\begin{array}{l}\text { Tungsten/ } \\
\text { Rhenium }\end{array}$ & $\mathrm{K}(1)$ & 1200 & 150 & 1.0 & $\begin{array}{l}\text { ZrC canned in } \\
\text { shell material }\end{array}$ & 1400 & 150 \\
\hline$\star T Z M$ & $k(1)$ & 1200 & 150 & 1.0 & $\begin{array}{l}\text { ZrC canned in } \\
\text { sheli material }\end{array}$ & 1400 & 150 \\
\hline
\end{tabular}


TABLE 9

BLANKET NO. 8 2-2ONE, K-COOLED

T BREEDING

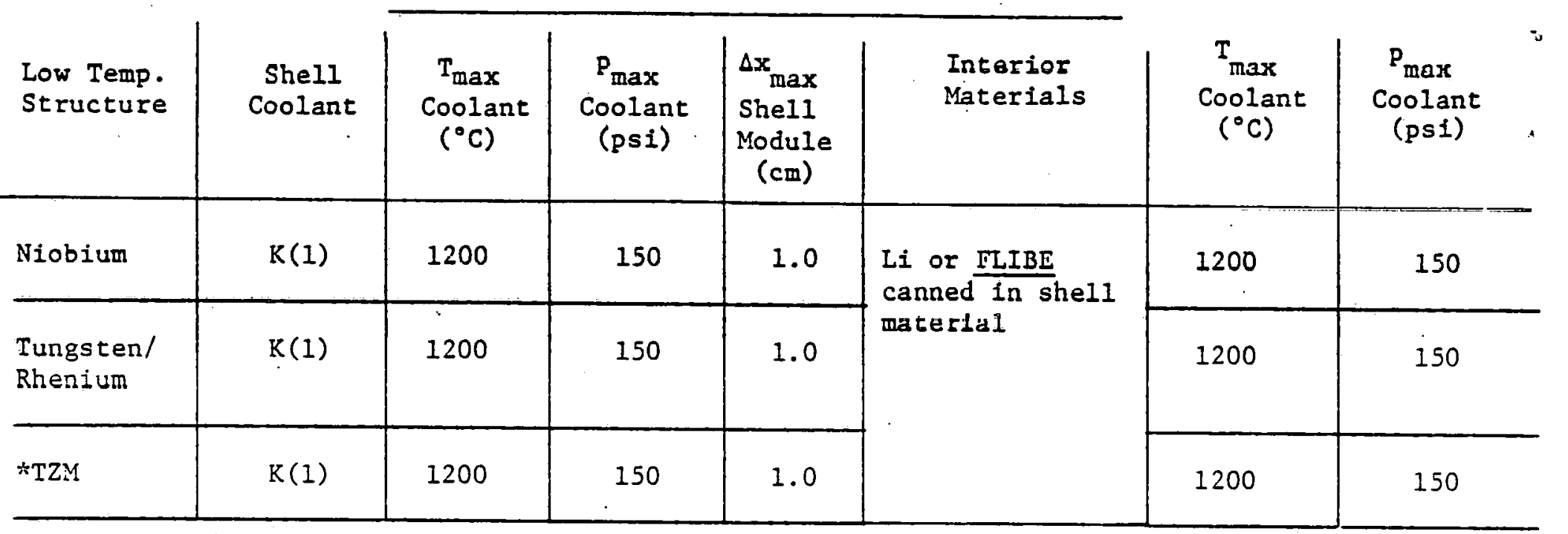




\section{GENERIC BLANKET FLOW SHEET \#7}

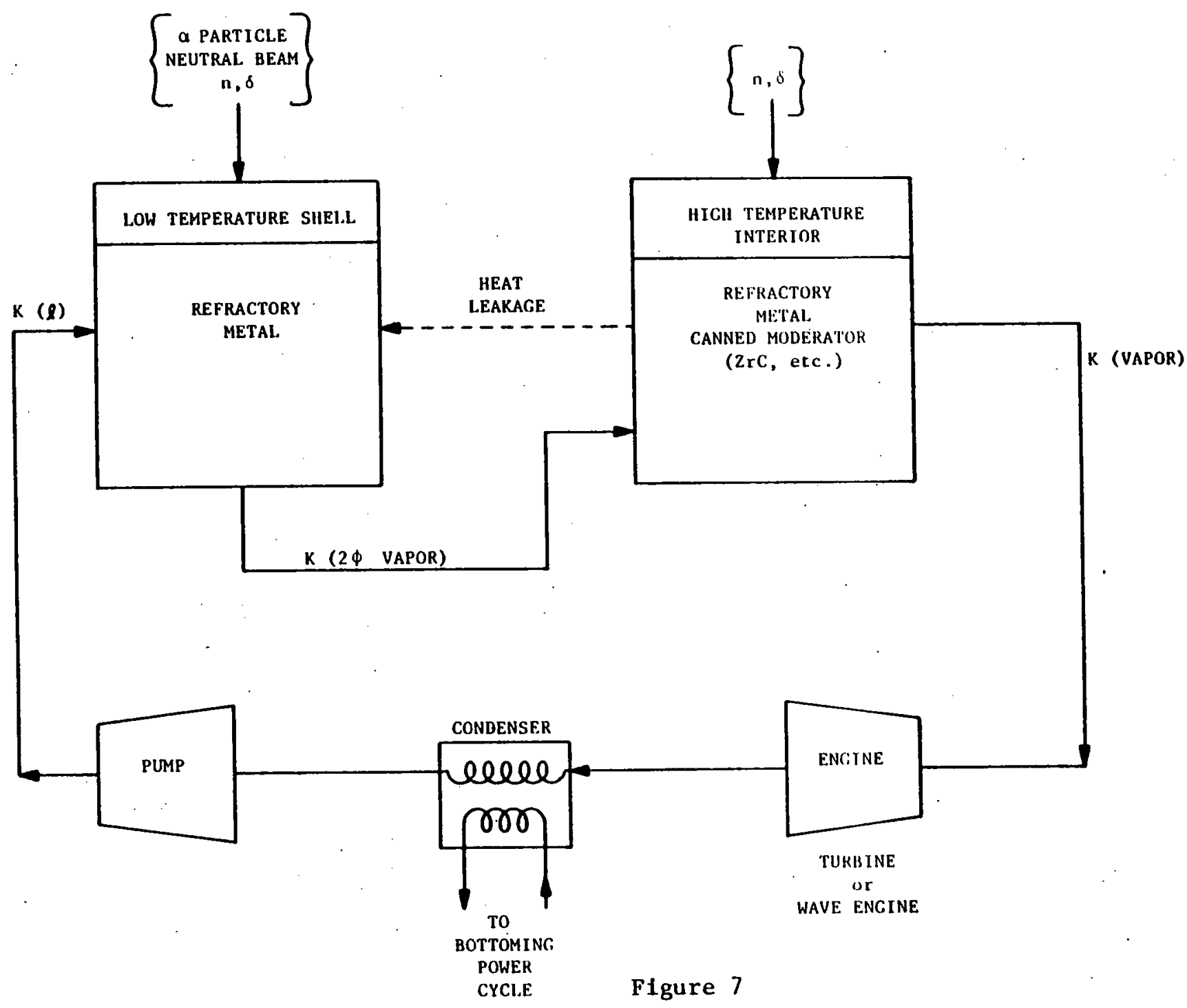




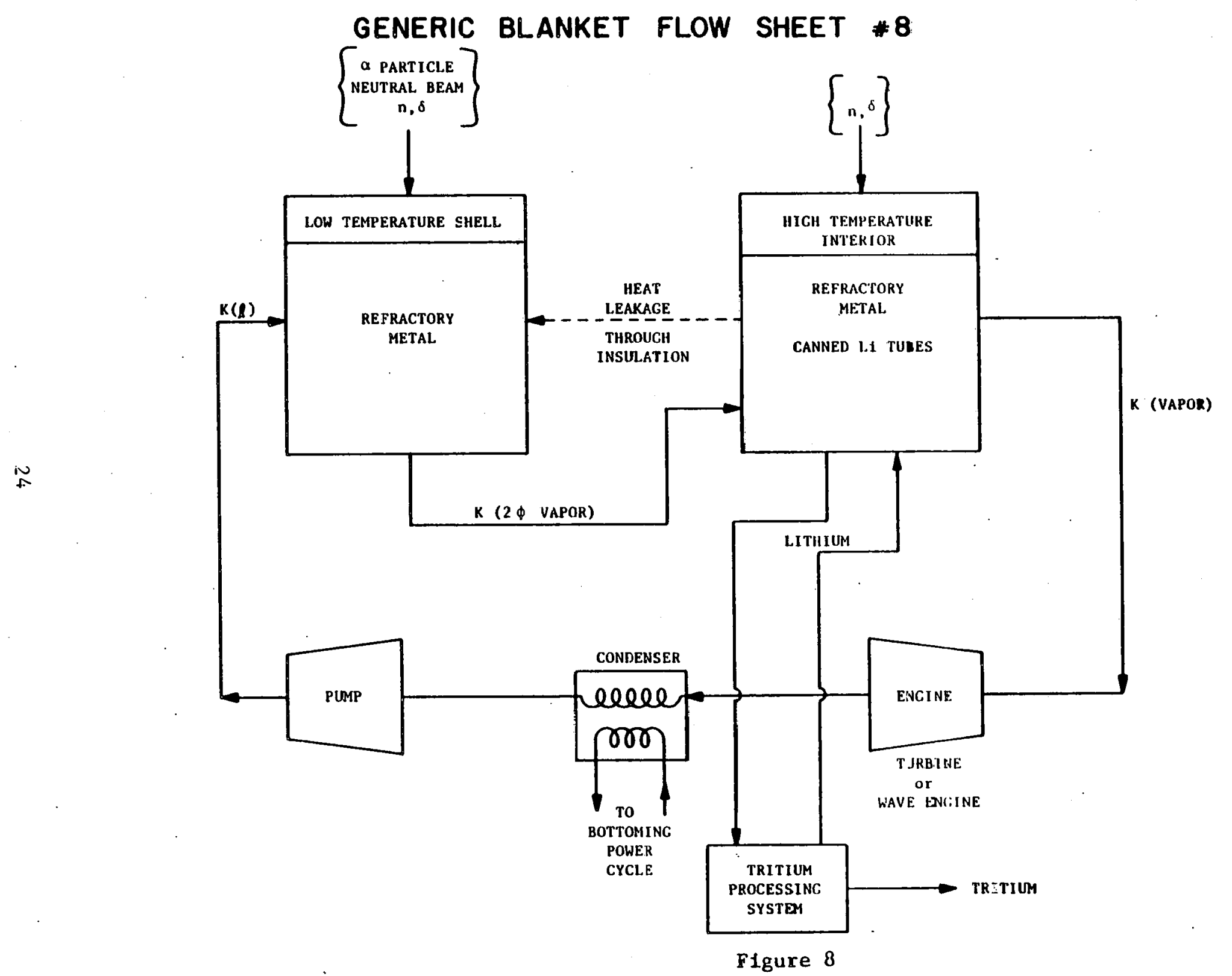


TABLE 10

\begin{tabular}{|c|c|c|c|c|c|c|c|}
\hline \multirow[b]{3}{*}{$\begin{array}{l}\text { Low Temp. } \\
\text { Structure }\end{array}$} & \multirow[b]{3}{*}{$\begin{array}{l}\text { Shell } \\
\text { Coolant }\end{array}$} & \multicolumn{2}{|c|}{ BLANKET NO. 9} & \multicolumn{2}{|c|}{ 1-ZONE, $\quad \mathrm{K}$-COOLED } & & \multirow[b]{3}{*}{$\begin{array}{l}P_{\max } \\
\text { Coolant } \\
\text { (psi) }\end{array}$} \\
\hline & & \multicolumn{4}{|c|}{ No BREEDING } & & \\
\hline & & $\begin{array}{l}\mathrm{T}_{\max } \\
\text { Coolant } \\
\left({ }^{\circ} \mathrm{C}\right)\end{array}$ & $\begin{array}{l}P_{\max } \\
\text { Coolant } \\
\text { (psi) }\end{array}$ & $\begin{array}{l}\Delta x_{\max } \\
\text { Shell } \\
\text { Module } \\
\text { (cm) }\end{array}$ & $\begin{array}{l}\text { Interior } \\
\text { Materials }\end{array}$ & $\begin{array}{l}T_{\max } \\
\text { Coolant } \\
\left({ }^{\circ} \mathrm{C}\right)\end{array}$ & \\
\hline Niobium & $K(\ell)$ & 1200 & 150 & 1.0 & ZrC canned in & 1200 & 150 \\
\hline $\begin{array}{l}\text { Tungsten/ } \\
\text { Rhenium }\end{array}$ & $\mathrm{K}(2)$ & 1200 & 150 & 1.0 & & 1200 & 150 \\
\hline$* \mathrm{TZM}$ & $\mathrm{K}(\ell)$ & 1200 & 150 & 1.0 & & 1200 & 150 \\
\hline
\end{tabular}


TABLE 11

BLANKET NO. 10 1-ZONE, K-COOLED

T BREEDING

\begin{tabular}{|c|c|c|c|c|c|c|c|}
\hline $\begin{array}{l}\text { Low Temp. } \\
\text { Structure }\end{array}$ & $\begin{array}{l}\text { Shell } \\
\text { Coolant }\end{array}$ & $\begin{array}{l}\mathrm{T}_{\max } \\
\text { Coolant } \\
\left({ }^{\circ} \mathrm{C}\right)\end{array}$ & $\begin{array}{l}P_{\max } \\
\text { Coolant } \\
\text { (psi) }\end{array}$ & $\begin{array}{l}\Delta x_{\max } \\
\text { Shell } \\
\text { Module } \\
\text { (cm) }\end{array}$ & $\begin{array}{l}\text { Incerior } \\
\text { Materials }\end{array}$ & $\begin{array}{c}T_{\max } \\
\text { Coolant } \\
\left({ }^{\circ} \mathrm{C}\right)\end{array}$ & $\begin{array}{c}P_{\max } \\
\text { Coolant } \\
\text { (psi) }\end{array}$ \\
\hline Niobium & $K(\ell)$ & 1200 & 150 & 1.0 & $\begin{array}{l}\text { Li or FLIBE in } \\
\text { shell material }\end{array}$ & 1200 & 150 \\
\hline $\begin{array}{l}\text { Tungsten/ } \\
\text { Rhenium }\end{array}$ & $K(2)$ & 1200 & 150 & 1.0 & & 1200 & 150 \\
\hline$* T Z M$ & $K(l)$ & 1200 & 150 & 1.0 & & 1200 & 150 \\
\hline
\end{tabular}




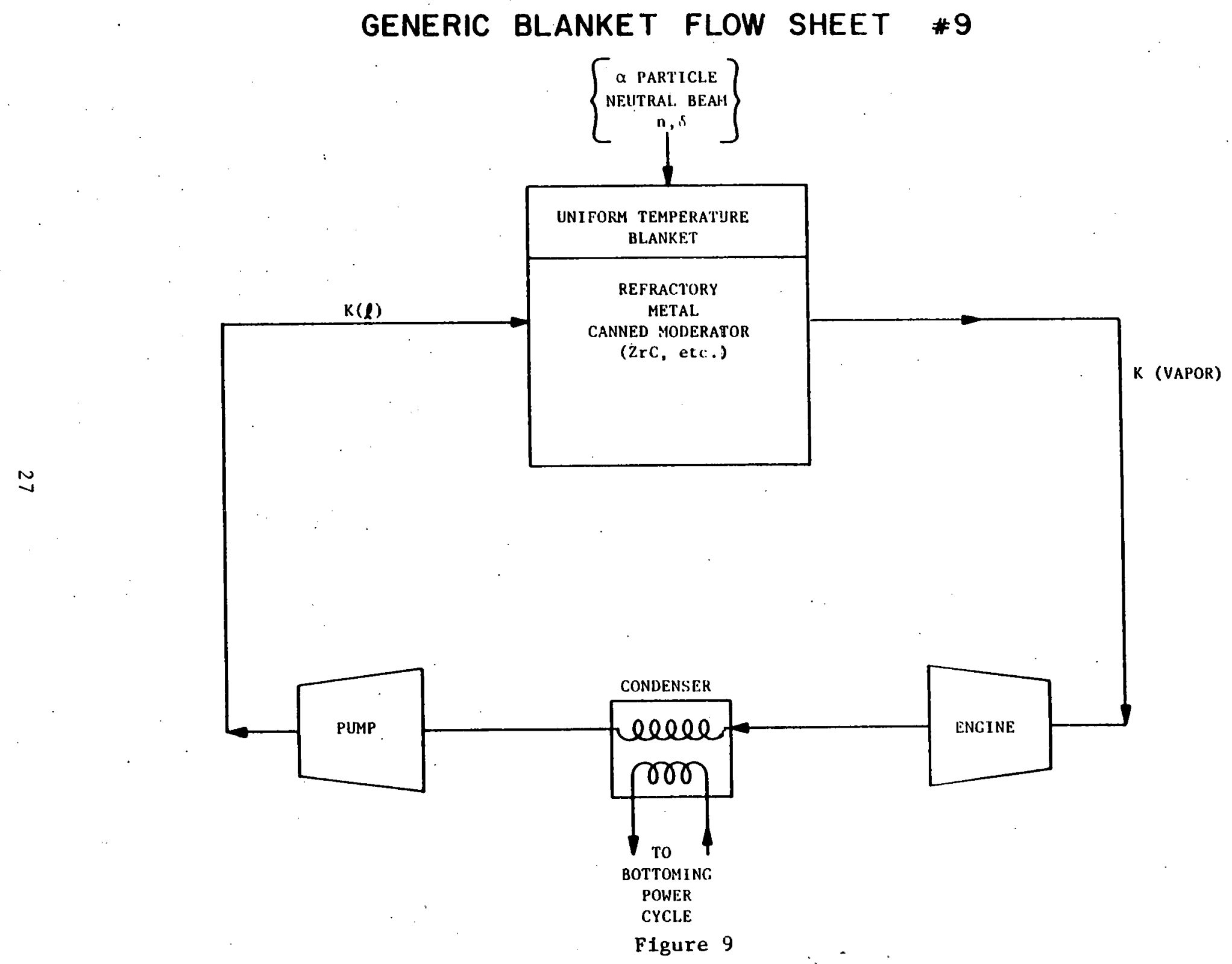




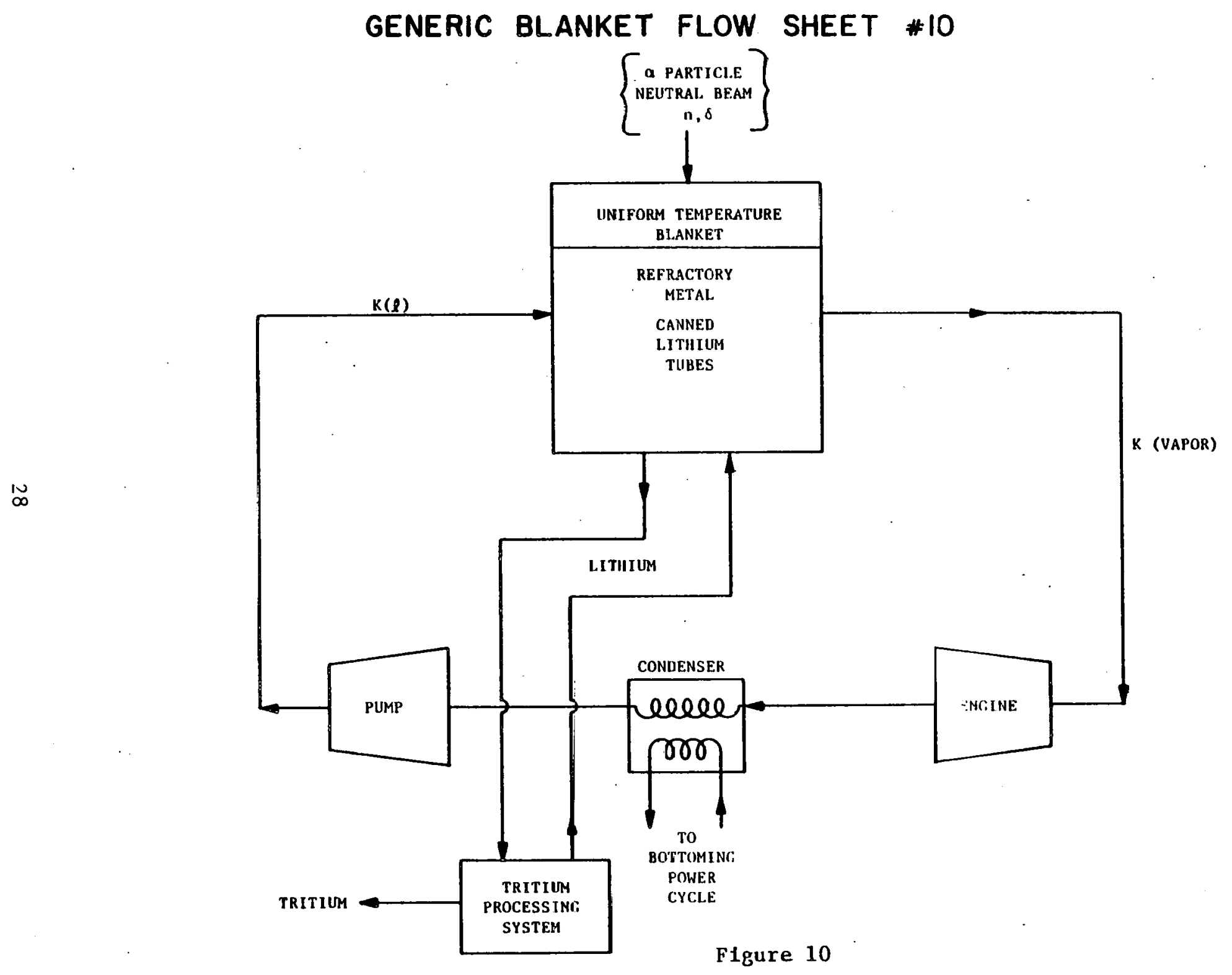


This concludes the prelimary description of the ten generic blanket types which were identified and the particular options which were selected for further analysis. There is an additional blanket approach which was also considered though not analyzed in any significant detail. In reality the blankets were developed to the point that flow sheets (Figures 11 and 12) could be prepared. This blanket approach allows the recovery of infected energy at the high temperatures desired for a high efficiency thermal power cycle. This concept involves depositing all of the fusion energy, including the radiolytic x-ray and plasma energy, in a high temperature ( $2000^{\circ} \mathrm{C}$ ) graphite block structure which surrounds the plasma. During the plasma burn period, the temperature of the block increases steadily; when the burn ceases, the deposited energy is removed by direct cooling with an inert gas stream that passes through channels in the graphite blocks into the plasma chamber. The chamber is rapidly pumped down by a two stage process (turbomolecular pumps followed by cryopumps) and the next burn initiated. Thermal hydraulic studies of this direct cooled blanket approach indicate that plasma burn times of $\sim 1000$ seconds can be accommodated with temperature increases of $\sim 500^{\circ} \mathrm{C}$ during the burn. Gas pumpdown studies indicate that adequately low pressures can be achieved in $\sim 200$ seconds, with $\sim 1 \%$ of the plant output recirculated to the pumpdown equipment. The energy extracted from the hot graphite structure during the dwell part of the plasma cycle is transferred to intermediate thermal storage from which it acts as a steady thermal source for the power cycle. All of the fusion and injected energy is available at high temperatures for the high efficiency efficiency power cycle. 
GENERIC BLANKET FLOW SHEET * II

[INTERMITTENT DIRECT COOLED]

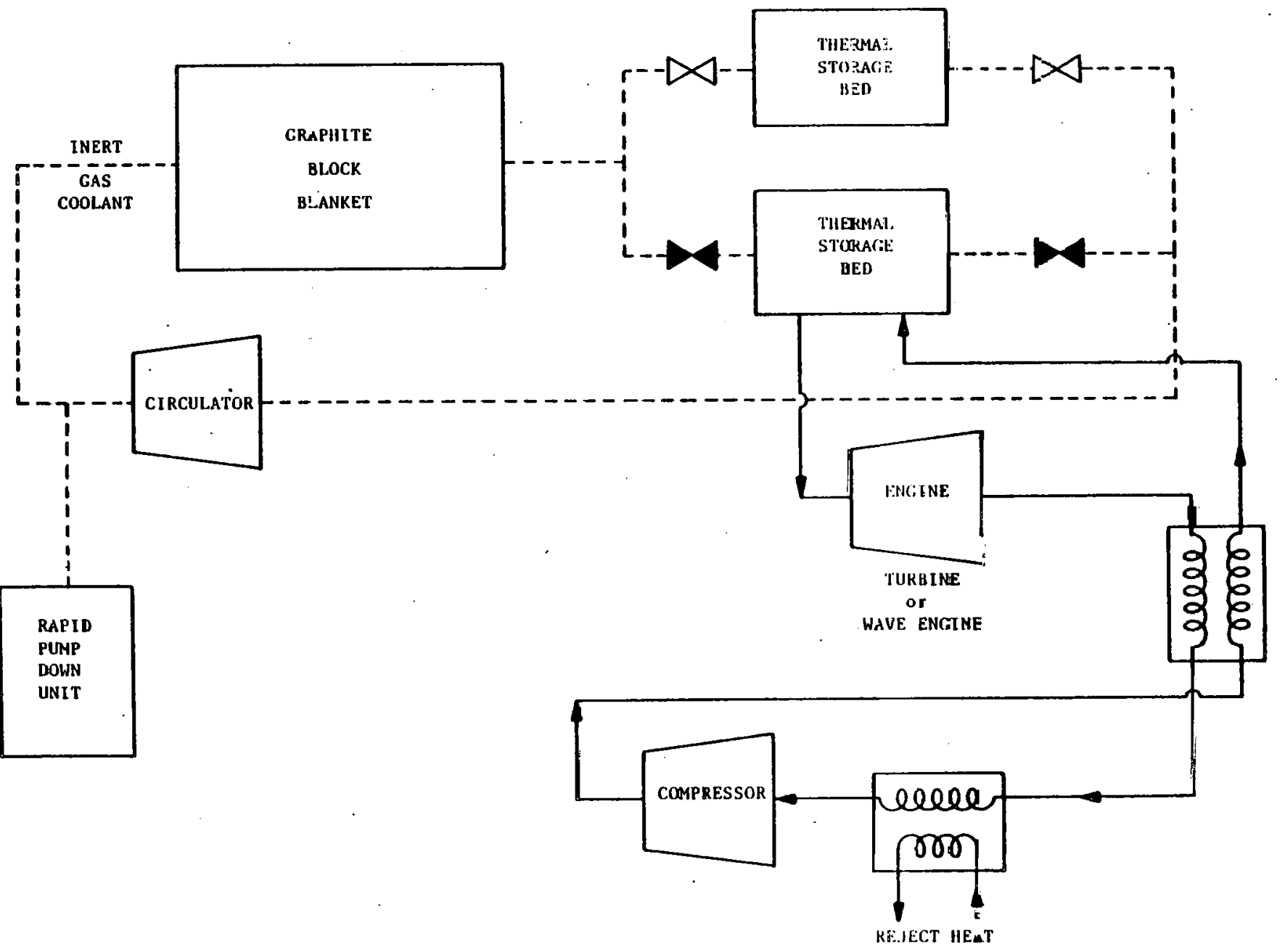

- - - - GAS CIRCILATION OPERATES ONI.Y WIEN PE.ASMA IS OFF

Figure 11 


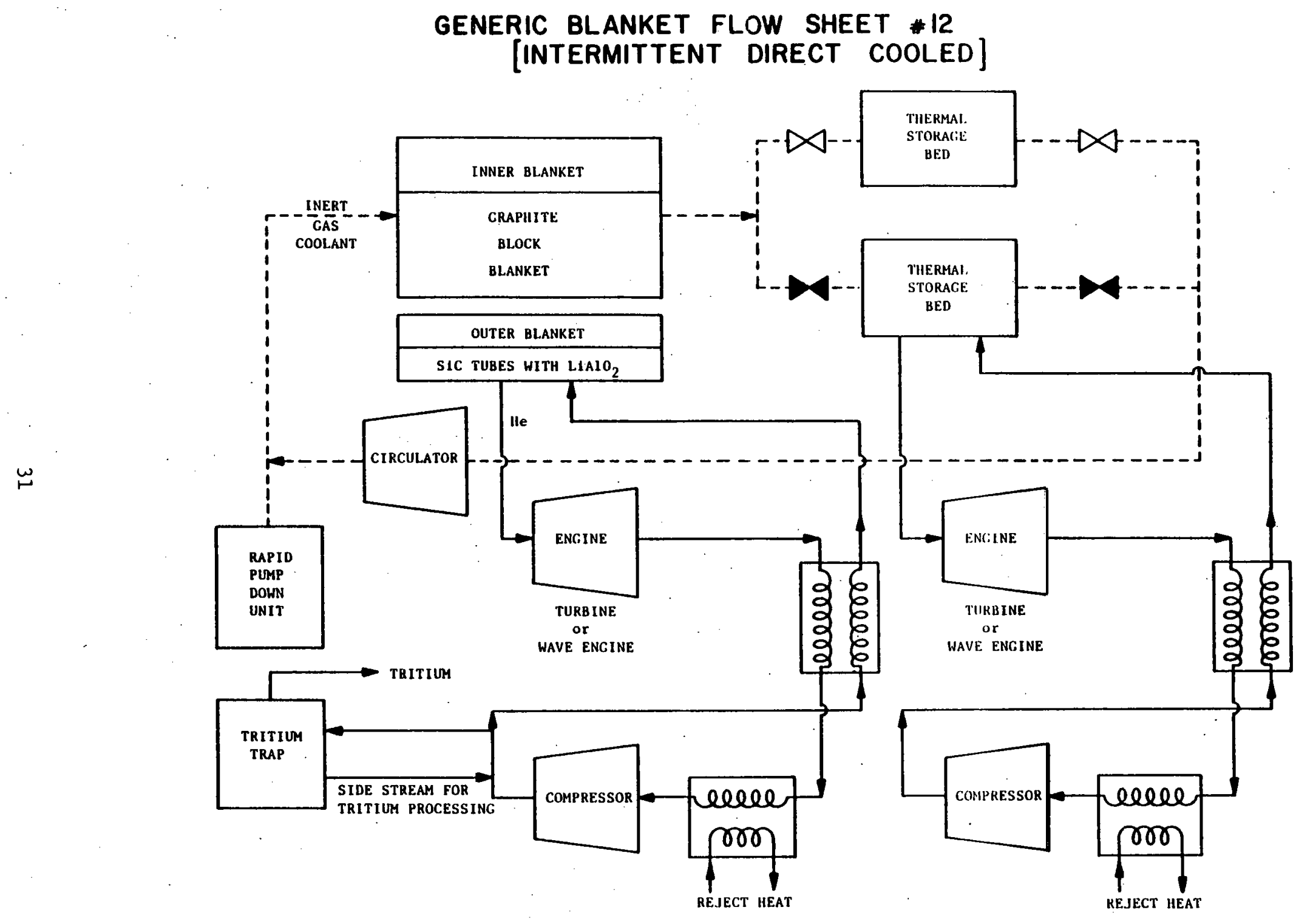

GAS CIRCULATION OPERATES ONLY WHEN PLASMA IS OFF

Figure 12 


\section{DESIGN RESULTS}

Each of the ten matertal and coolant options selected in the previous section have undergone neutronic and thermal hydrualic analyses. These results are summarized for each of the ten blankets in this section.

A nucleonic (neutronic and photonic) analysis was performed on each of the ten generic blankets. This analysis consisted of the following steps: (1) determination of the equivalent geometry and atomic concentrations of the blanket module, (2) neutron and photon fluxes are found by performing a transport calculation using the computer program ANISN ${ }^{(5)}$ together with the 121 energy group (100 neutron groups and 21 photon groups) coupled neutron-photon cross section set, EPR ${ }^{(6)}$. Cylindrical geometry, with a $\mathrm{P}_{3}-\mathrm{S}_{8}$ expansionquadrature was used, (3) nucleonic fluxes were folded with appropriate kerma factors and reaction cross-sections to calculate heating rates and, where applicable, breeding ratios.

A representative blanket module for the first group of blankets (types 1-4) is shown in Figure 13. A number of module sub-sections are mounted on a rigid backing plate and are inserted or removed from the reactor as a unit. The long straight sides of each sub-section have a $2 / 1$ elliptical head facing the plasma, with the sub-sections placed next to each other on the backing plate. The structural shells that form each sub-section are cooled by an attached array of small tubes, carrying a coolant such as water. The hot interior is insulated from the shell by a fibrous mat layer of graphite (blanket types 1 and 2 ) or refractory oxide (blanket types 3 and 4 ). The coolant for the hot interior passes through the packed refractory bed, either along the long axis of the module or radially from integral header tubes.

A cross-section of blanket type 1 is shown in Figure 13. The materials used 
BLANKET TYPE 1

NEUTRON FLUX FROM PLASMA
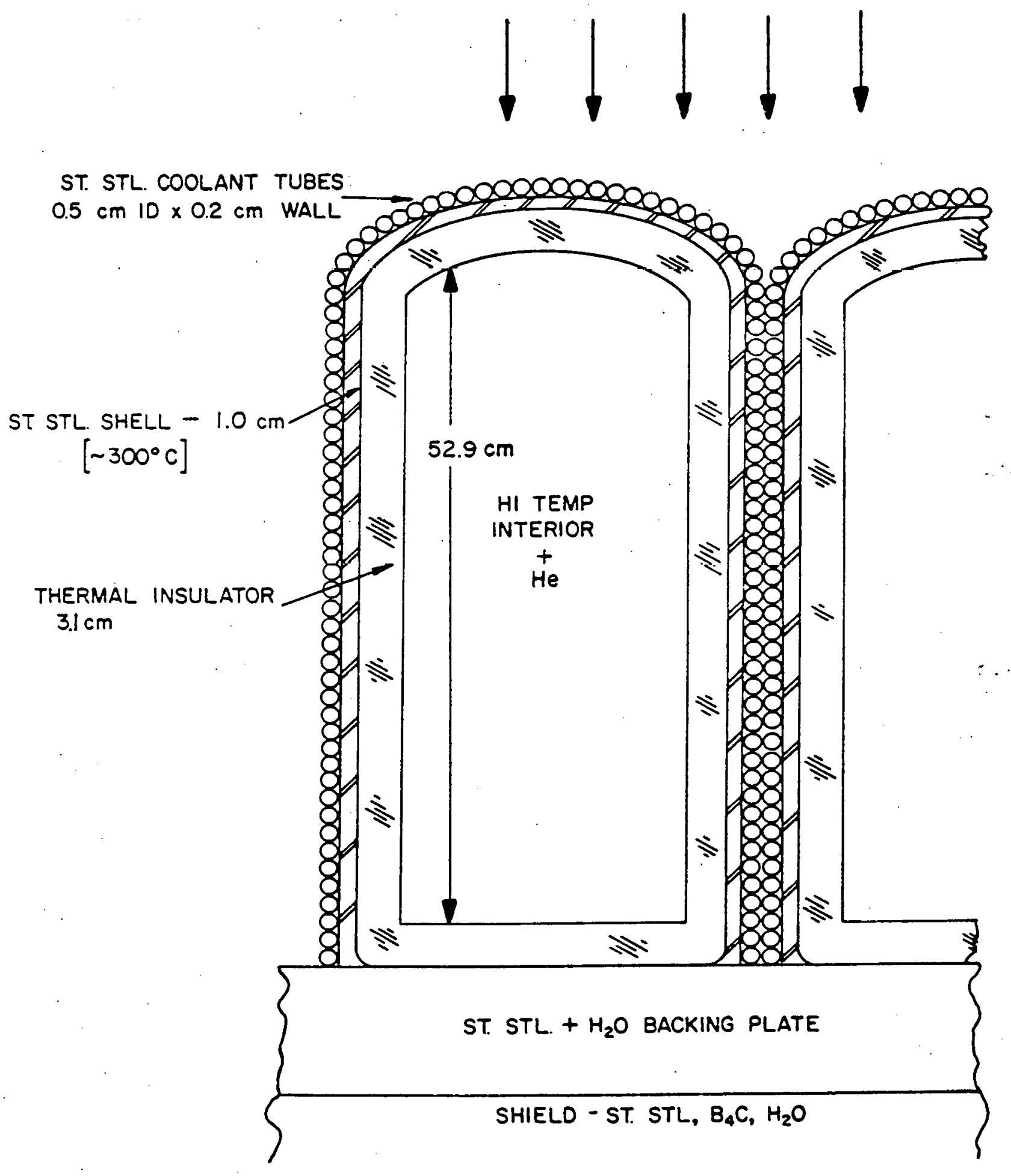

Figure 13 
in this blanket are listed in Table 12. The stainless steel coolant tubes contain water, and the thermal insulator regton separates the hot interior (SiC) from the cooler structural material and first-wall regions. The backing plate and shield are of similar design in all ten of the blankets presented here. The total and $14 \mathrm{MeV}$ neutron fluxes for blanket type 1 are shown in Figure 14. The distance parameter is measured from plasma center and this coordinate has been adfusted in performing step (1) in nucleonic analysis. One can see that the $14 \mathrm{MeV}$ neutron flux is reduced by a factor of $\sim 350$ over the blanket and by a factor of $\approx 150$ over the hot interfor. These factors indicate large fractions of energy deposition in the blanket and particluarly in the hot interior. This fact is verified by Figure 15, an 1llustration of the total energy deposition across the blanket region. For blanket type 1 only $\sim 8 \%$ of incident energy penetrates beyond the blanket region, and $58 \%$ of the total energy is deposited in the hot interior.

Using blanket type $I$ as a base case as delineated in Table 13, a number of design vartations were performed (see Table 13, 1B-1J) to increase the fraction of energy deposited in the high temperature interfor. The effect of these design variations is summarized in Table 14. The fraction of neutron and gamma energy deposited in the various blanket/shield regions is given, along with the fraction of total fusion energy (including alpha particle energy) that appears as high temperature heat in the hot interior of the module (thermal leakage through the insulation is not included).

The base case design yields a fractional fusion energy deposition in the hot interior of $58 \%$ (Including alpha particle energy). The thickness of the module shell has a large effect on high temperature efficiency, with a change of $\pm 4 \%$ from the original value of $58 \%$ per $\mp 0.25 \mathrm{~cm}$ change in shell thickness (cases $I B$ and $1 C$ ). Changing shell materlal to aluminum from stainless steel has 
Table 12

Blanket Type \# 1

Region

Coolant Tubes

Shell

Insulator

Hot Interior

Backing Plate

Shield
Material

316 SS

$\left(\mathrm{H}_{2} \mathrm{O}\right)$

316 SS

$\operatorname{SiC}(10 \%)$

SiC $(80 \%)$

(He)

316 SS

$\left(\mathrm{H}_{2} \mathrm{O}\right)$

316 SS (20\%)

$\mathrm{B}_{4} \mathrm{C} \quad(80 \%)$

$\left(\mathrm{H}_{2} \mathrm{O}\right)$
Dimensions

$0.5 \mathrm{~cm}$ ID

$0.2 \mathrm{~cm}$ wall

$0.75 \mathrm{~cm}$ thick

$3.1 \mathrm{~cm}$ thick

$52.9 \mathrm{~cm}$ high $22.3 \mathrm{~cm}$ wide

$15 \mathrm{~cm}$ thick

$100 \mathrm{~cm}$ thick

Hot Interior Energy Fraction

Breeding Ratio

None 


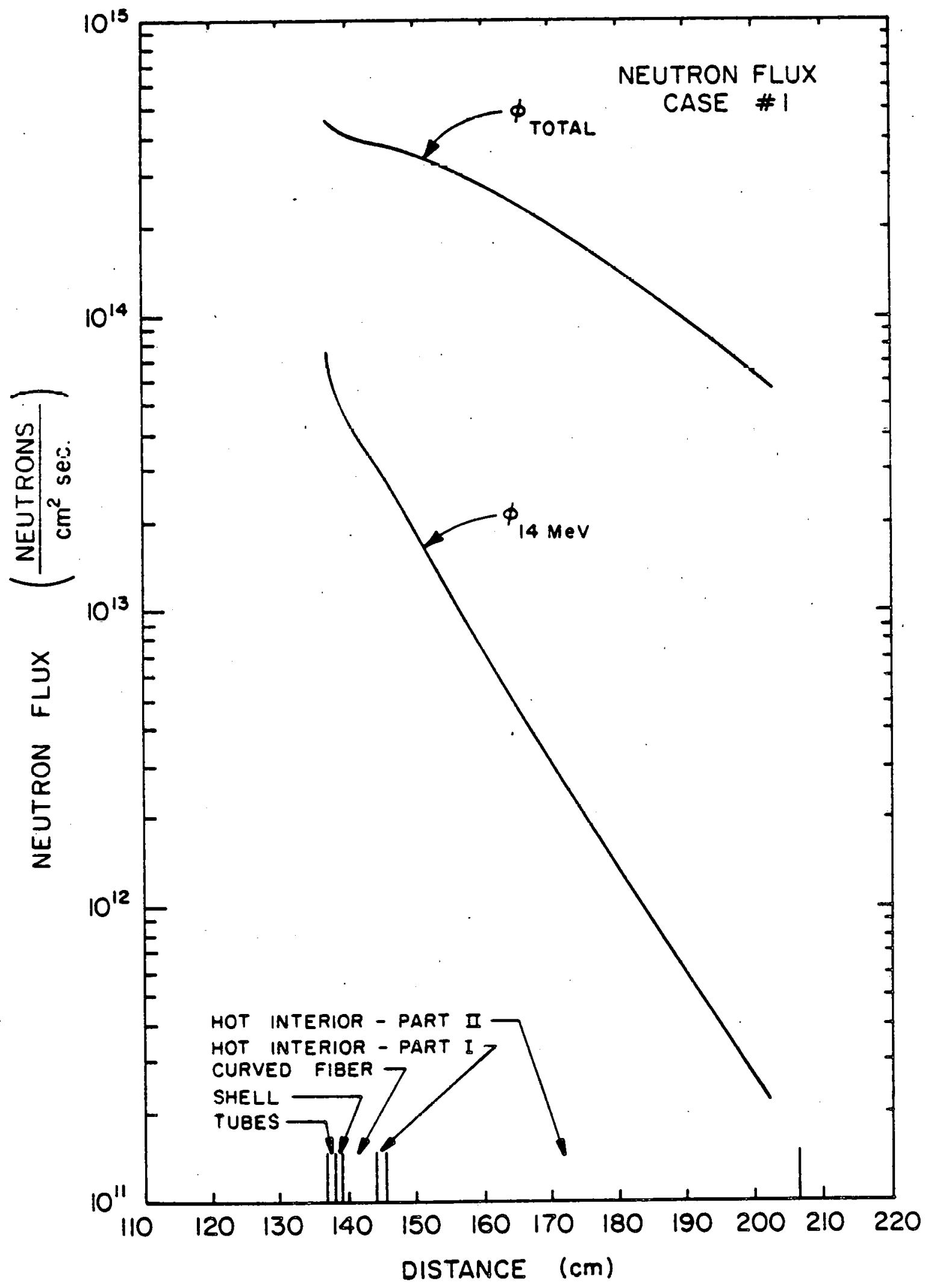

Figure 14 


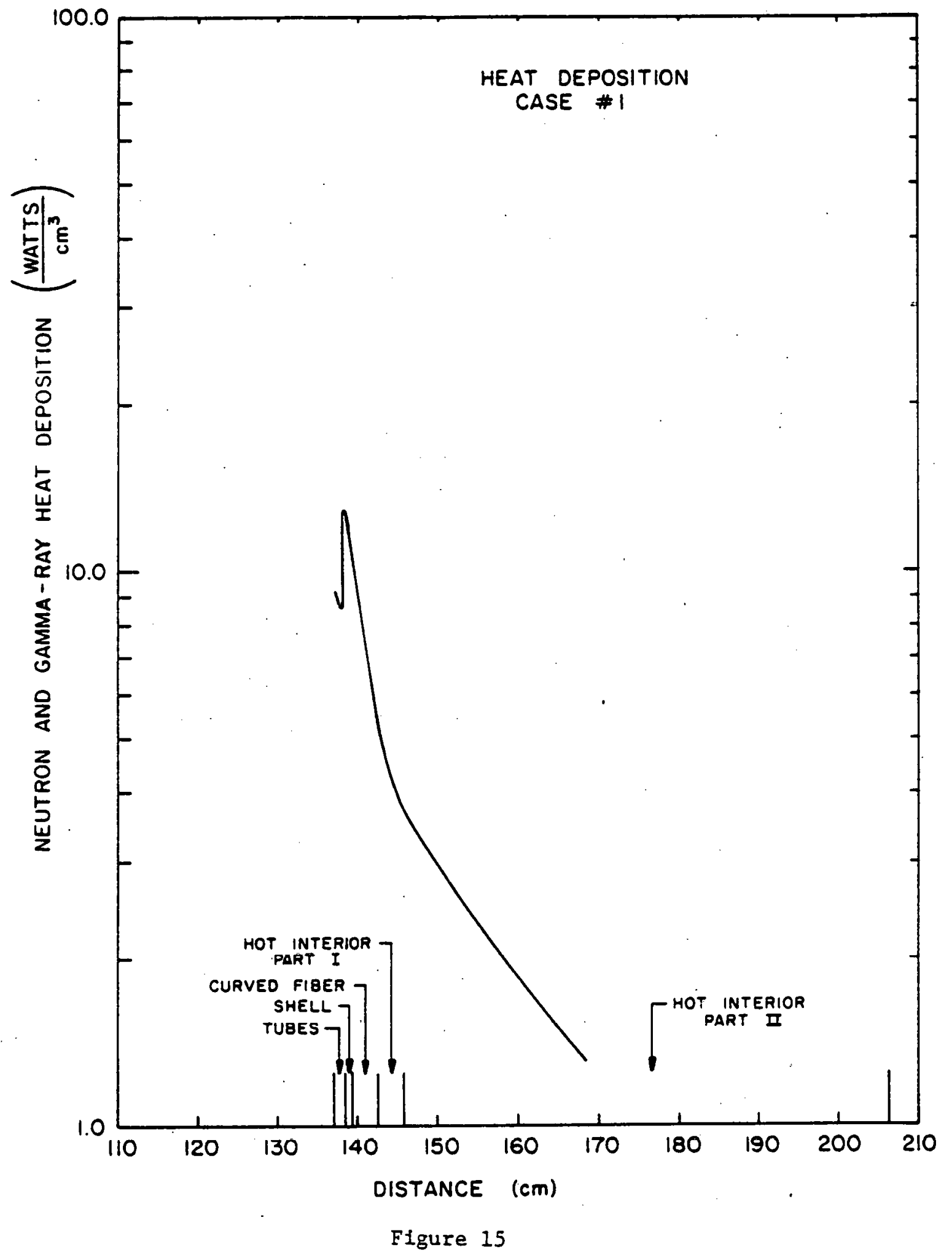


Sensitivity Studies for Two Temperature Zone Blanket (Blanket Type \#1)

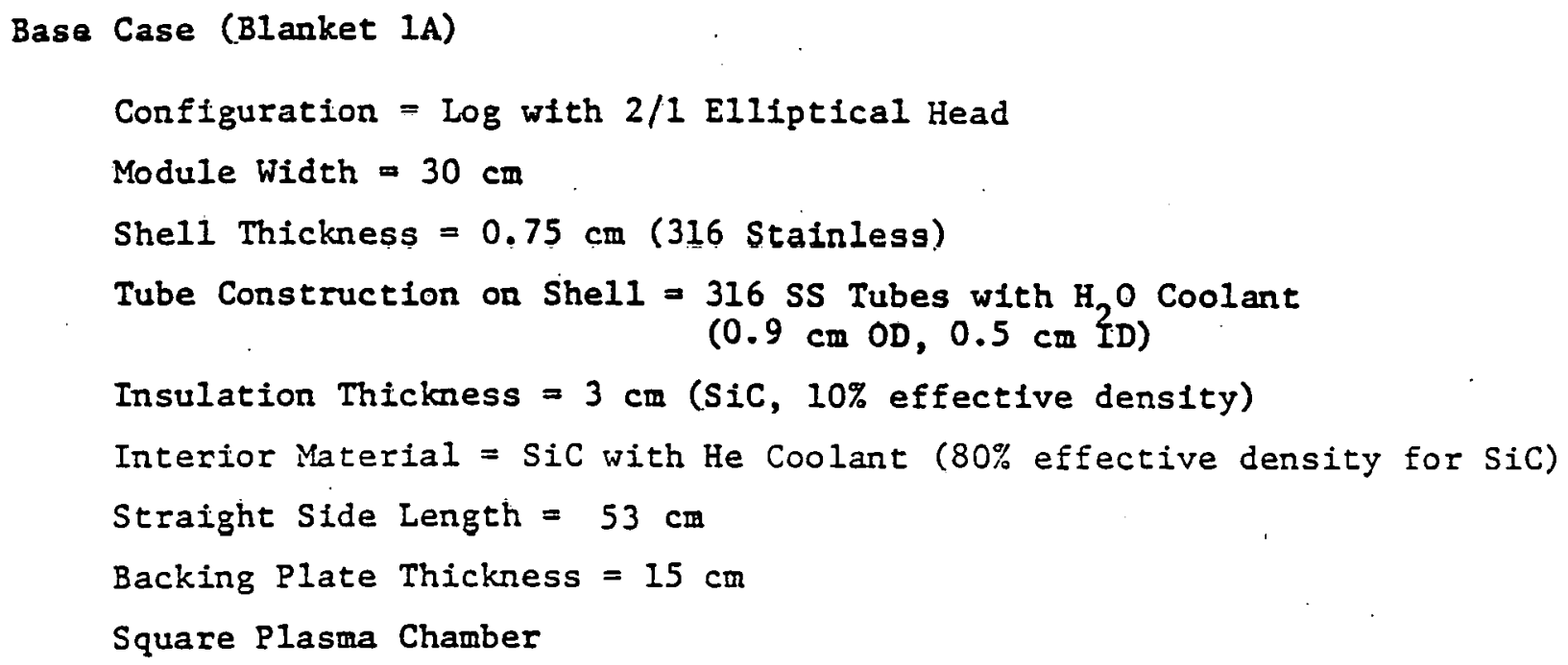


Table 14

Results of Sensitivity Studies for Two Temperature Blankets

(Blanket Type \#1)

\% of Neutron and Gamma Deposition in Blanket Region

\begin{tabular}{|c|c|c|c|c|c|c|c|c|c|c|}
\hline \multirow{3}{*}{$\begin{array}{l}\text { Blanket Region } \\
\text { Blanket Region }\end{array}$} & \multirow{3}{*}{$1 \mathrm{~A}$} & \multirow{3}{*}{$1 \dot{\mathrm{B}}$} & \multirow{3}{*}{$1 \mathrm{C}$} & \multirow{3}{*}{ 1D } & \multicolumn{2}{|c|}{ Case \# } & \multirow{3}{*}{$1 G$} & \multirow{3}{*}{$1 \mathrm{H}$} & \multirow{3}{*}{ 1I } & \multirow{3}{*}{$1 \mathrm{~J}$} \\
\hline & & & & & $1 \mathbf{E}$ & $1 F$ & & & & \\
\hline & & & & & & & & & & \\
\hline Tubes & 9 & 10 & 9 & 9 & 10 & 6 & 9 & 10 & 9 & 9 \\
\hline She11 & 10 & 7 & 13 & 10 & 11 & 5 & 9 & 10 & 10 & 10 \\
\hline $\begin{array}{l}\text { Insulation } \\
\text { Fiber in Head }\end{array}$ & 2 & 2 & 2 & 2 & 2 & 2 & 2 & 1 & 2 & 2 \\
\hline $\begin{array}{l}\text { Ceramic in } \\
\text { Head }\end{array}$ & 9 & 10 & 8 & 9 & 11 & 11 & 8 & 16 & 10 & 18 \\
\hline $\begin{array}{l}\text { Straight } \\
\text { Section }\end{array}$ & 61 & 62 & 60 & 65 & 61 & 64 & 61 & 57 & 62 & 51 \\
\hline Back Fiber & 0 & 0 & 0 & 0 & 0 & 0 & 1 & 0 & 0 & 0 \\
\hline Backing Plate & 8 & 9 & 8 & 3 & 5 & 6 & 9 & 6 & 6 & 9 \\
\hline Shteld & 0 & 1 & 0 & 2 & 0 & 5 & 1 & 0 & 0 & 1 \\
\hline $\begin{array}{l}\% \text { of Fusion } \\
\text { Energy in }\end{array}$ & & & & & & & & & & \\
\hline $\begin{array}{l}\text { Hot Interior } \\
\text { (Including } \\
\text { parttcle } \\
\text { energy) }\end{array}$ & 58 & 63 & 54 & 61 & 61. & 69 & 58 & 63 & 61 & 62 \\
\hline
\end{tabular}


a large effect on high temperature efficiency, increasing it from the original $58 \%$ to $69 \%$ (case $1 F$ ). Decreasing insulation thickness (case $1 \mathrm{H}$ ) to $1.0 \mathrm{~cm}$ from the original $3.1 \mathrm{~cm}$ also significantly tncreases the high temperature efficiency (from 58\% to 63\%). Smaller Increases (e.8., to 62,61 , and 61 respectively) are obtained by increasing the module width, making it radially thicker, substituting MgO for SIC, and increasing the density of the interior material (cases IJ, 1D, $1 E$, and $1 I)$. Changing the shape of the plasma chamber from square to round had no significant effect on the high temperature effictency.

Not studied were the effects of using $\mathrm{D}_{2} \mathrm{O}$ coolant instead of $\mathrm{H}_{2} \mathrm{O}$ in the coolant tubes attached to the lower temperature module shell, and the effects of using an interior material with a substantially higher kerma factor, e.g., molybdenum carbide. The former will probably have relatively small effect, since the effective thickness of the $\mathrm{H}_{2} \mathrm{O}$ coolant is small; the latter should have a substantial effect, however.

Two dimensional neutronic transport analyses (Twotran) have been carried out on two temperature blankets of the types considered here ${ }^{(7)}$. Results for the fraction of energy depostted in the hot interior computed by two-dimensional analyses agree fairly closely with those for one-dimensional analyses, except that the former are generally a few percent lower. The analysis consisted of the following steps: (1) Determination of the equivalent geometry and atomic concentrations of the blanket module for the computer simulation. (2) The onedimensional nucleonic (neutron and photon) flux was found by performing a transport calculation using the computer program ANISN ${ }^{(5)}$ together with the 121 energy group (100 neutron and 21 photon groups) coupled neutron-photon cross-section set, EPR ${ }^{(6)}$. Spherical geometry, with a $\mathrm{P}_{3}-\mathrm{S}_{8}$ expansion-quadrature, was used. The system was modeled as a spherical shell with a point source of $14 \mathrm{MeV}$ neutrons at its center. (3) An appropriate collapsed energy group structure was 
chosen for use in the two-dimensional calculation. (4) The two-dimensional nucleonic flux was determined with a $\mathrm{P}_{3}-\mathrm{S}_{8}$ expansion-quadrature run of the computer program TWOTRAN-II ${ }^{(8)}$. R-Z cyclindrical geometry was used, with the Z-axis as the axis of symetry of the module, and the R-axis perpendicular to the 2-axis. The source was modeled as a $1.4 \mathrm{MeV}$ neutron beam directed along the +z-axis, with a small angular spread. (5) The two-dimensional heating analysis was performed by using the nucleonic flux, the collapsed 20 group kerma factors, and the atomic concentrations. In the case examined in reference (7), the hot interfor absorbed $82 \%$ of the total nucleonic heat absorbed by the module, indicating a very promising high efficiency blanket concept. Blanket type 2 is illustrated in Figure 16 and Table 15. The stainless steel tubes again contain water, the breeding material chosen is $\mathrm{LiAlO}_{2}$, and $\mathrm{BeO}$ is utilized as a neutron multiplier. Initially, a breeding ratio of .82 was obtained for this blanket. An increase in thickness of the breeding zone by $50 \%$ raised the breeding ratio to .91 . Further improvements such as those envisioned for blanket type 1 could be utilized to increase the breeding ratio and thus blanket type 2 would be a viable breeder.

Blanket type 3 is a two-zone concept which is entirely water and steam cooled. This blanket type is shown in Figure 17 and Table 16. This design is similar to blanket type 1 , and the improvements in the amount of energy absorbed proposed for blanket type 1 could be reiterated here. Blanket type 4 (Table 17) is the breeding version of blanket type 3 and has been examined in more detail. BeO and $\mathrm{LiAlO}_{2}$ are included in the hot interior and a breeding ratio of 1.06 results. It should be emphasized again that this ratio has not been optimized. In fact, with $\mathrm{Al}_{2} \mathrm{O}_{3}$ used as insulator and steam coolant only $\sim 17 \%$ of the energy is deposited in the hot interior. A study of the type performed for blanket type 1 then appears necessary to increase this percentage. 


\section{NEUTRON FLUX FROM PLASMA}

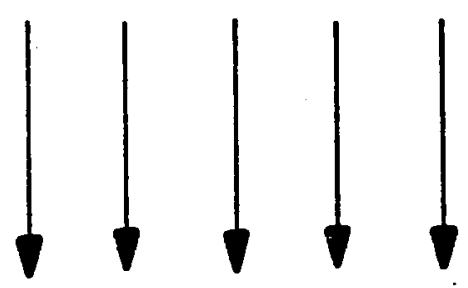

ST. STL. COOLANT TUBES

$0.5 \mathrm{~cm} \mathrm{ID} \times 0.2 \mathrm{~cm}$ WALL

THERMAL INSULATOR-3

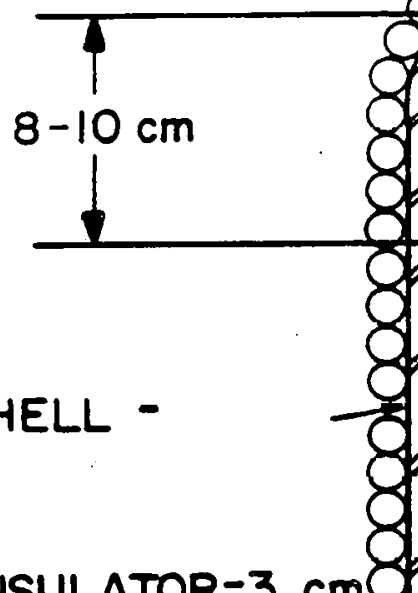

ST. STL. SHELL -

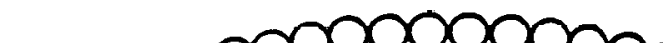

\section{(1)}


Table 15

Blanket Type \# 2

$\underline{\text { Region }}$

Coolant Tubes

Shell

Insulator

Breeding Zone

Hot Interior

Blacking Plate

Shield

Hot Interfor Energy Fraction

Breeding Ratio
Material

316 SS

$\left(\mathrm{H}_{2} \mathrm{O}\right)$

316 SS

$\operatorname{SiC}(10 \%)$

$\mathrm{BeO}(60 \%)$

$\mathrm{LiAlO}_{2}$ (5\%)

( $\mathrm{He})$

SiC $(80 \%)$

(He)

(See Table 12)
Dimensions

$$
\begin{gathered}
0.5 \mathrm{~cm} \text { ID } \\
0.2 \mathrm{~cm} \text { wall }
\end{gathered}
$$

$0.75 \mathrm{~cm}$ thick

$3.0 \mathrm{~cm}$ thick

$10 \mathrm{~cm}$ thick

$+2 \mathrm{~cm}$ at edge of hot interior

$43 \mathrm{~cm}$ thick 
BLANKET TYPE 3

\section{NEUTRON FLUX FROM PLASMA}
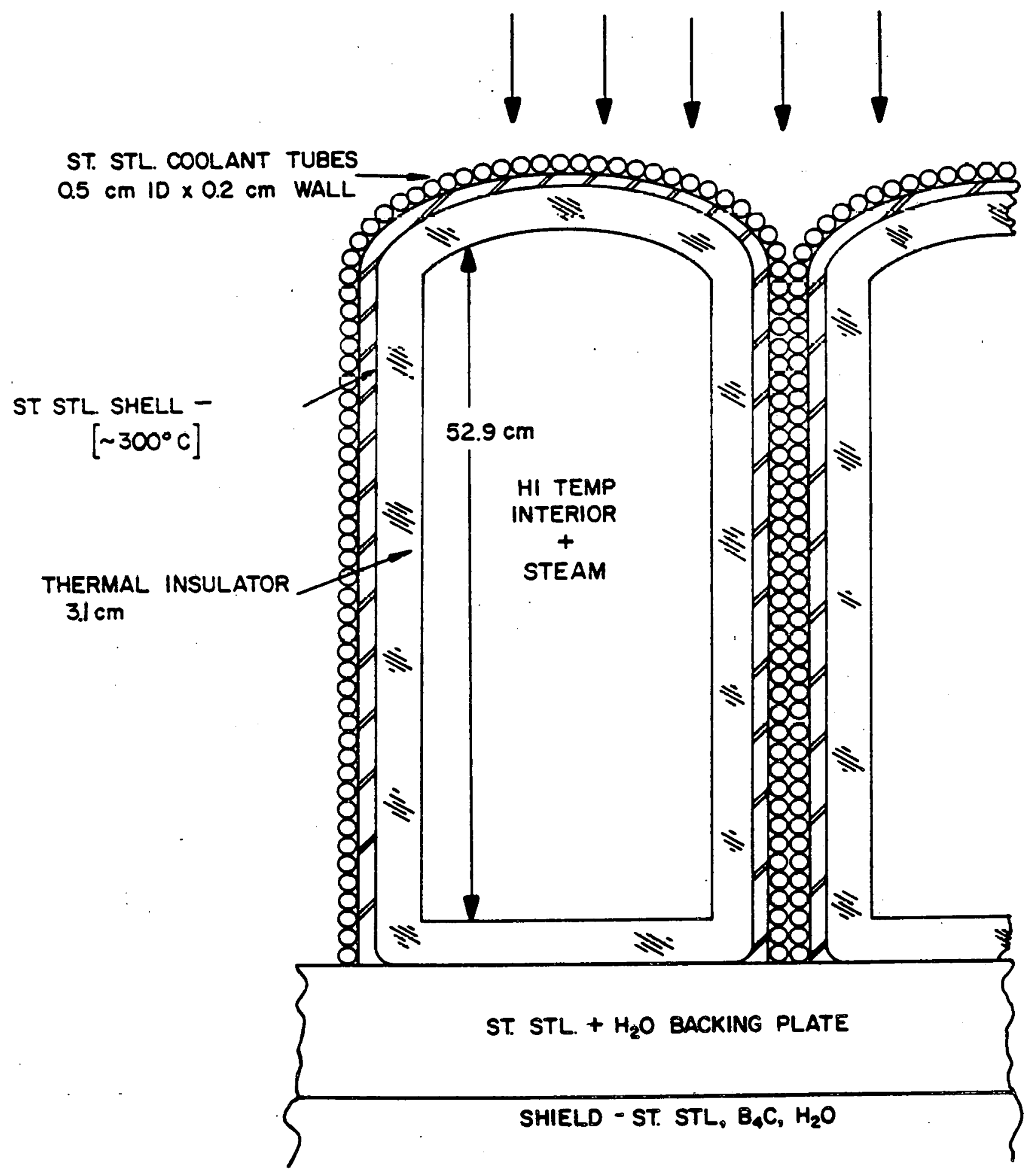

F1gure 17 
Table 16

Blanket Type \# 3

\section{$\underline{\text { Region }}$ \\ Coolant Tubes}

Shell

Insulator

Hot Interior

Backing Plate

Shield
Material

316 SS

$\left(\mathrm{H}_{2} \mathrm{O}\right)$

316 SS

$\operatorname{sic}(10 \%)$

SIC $(80 \%)$

$\left(\mathrm{H}_{2} \mathrm{O}\right)$

316 SS

$\left(\mathrm{H}_{2} \mathrm{O}\right)$

316 SS (20\%)

$\mathrm{B}_{4} \mathrm{C} \quad(80 \%)$

$\left(\mathrm{H}_{2} \mathrm{O}\right)$
Dimensions

$0.5 \mathrm{~cm} \mathrm{ID}$

$0.2 \mathrm{~cm}$ wall

$0.75 \mathrm{~cm}$ thick

$3.1 \mathrm{~cm}$ thick

$52.9 \mathrm{~cm}$ high

$22.3 \mathrm{~cm}$ wide

$15 \mathrm{~cm}$ thick

$100 \mathrm{~cm}$ thick

Hot Interior Energy Fraction

$58 \%$

Breeding Ratio

None 


\section{Table 17}

\section{Blanket Type \# 4}

\section{Region}

Coolant Tubes

Shell

Insulator

Breeding 7nne

Hot Interior
Material

316 SS

$\left(\mathrm{H}_{2} \mathrm{O}\right)$

316 SS

$\mathrm{Al}_{2} \mathrm{O}_{3}$ (10\%)

DeO (77\%)

$\mathrm{LiAlO}_{2}(14 \%)$

$\left(\mathrm{H}_{2} \mathrm{O}\right)$

$\operatorname{SiC}(80 \%)$

$\left(\mathrm{H}_{2} \mathrm{O}\right)$
Dimensions

$0.5 \mathrm{~cm}$ ID

$0.2 \mathrm{~cm}$ wall

$0.75 \mathrm{~cm}$ thick

$3.1 \mathrm{~cm}$ thick

$18 \mathrm{~cm}$ thick

$+2 \mathrm{~cm}$ sides of hot interior

$38 \mathrm{~cm}$ thick

Backing Plate

Shield

(See Table 12)

Hot Interior Energy Fraction

Breeding Ratio

$1.06 \%$ 
Neutron fluxes and heat deposition profiles are shown in Figures 18 and 19. The separator region of the hot interior (separating oreeding and non-breeding zones) composed largely of stainless steel seems to contribute a great deal to the reduction in heat deposition. Further analysis of this effect is indicated in IIne with optimization studies mentioned previously.

The second group of Blanket types ut $\$ 1$ izes one-zone temperature blankets. A refractory metal shell (TZM or niobium) is used with a refractory interior (S1C or other refractory carbide) and hellum cooling. The module geometry is cylindrical, with the axis of the cylinder normal to the plasma surface, and a hemispherical head on the end facing the plasma (Figure 20). The inert gas coolant is distributed from an internal header system, first cooling the module shell and then returning through the interior. In practice, the interior will operate at somewhat higher temperature than the shell due to the sensible heat pickup hy the inert gas coolant as it passes through the module. Maximum coolant exit temperatures will be on the order of $1000^{\circ} \mathrm{C}$. Blanket types 5 and 6 are shown in Figures 21 and 22 and Tables 18 and 19, respectively. These blankets are one-zone helium-cooled with TZM exteriors and largely SiC interiors. Due to a lack of TZM kerma factors, the only nucleonics analysis that was performed was the neutron flux profile shown for blanket type 6 in Figure 23 . Some optimization was performed on this design when tt was discovered that molybdenum had a large neutron capture cross-section which was detrimental to breeding. The breeding ratio was increased from .28 to .68 in the course of this analysis. The original breeding ratio of .28 was raised to 0.40 by increasing the thickness of the breeding zone (Figure 22) from $10 \mathrm{~cm}$ to $25 \mathrm{~cm}$. The breeding ratio was next increased to 0.53 by increasing the lithium enrichment from $50 \%$ to $90 \%$. The final increase of the breeding ratio to 0.68 was obtained by doubling the lithium concentration to $10 \%$ and decreasing the $\mathrm{Be}$ and $\mathrm{SiC}$ volume fractions 


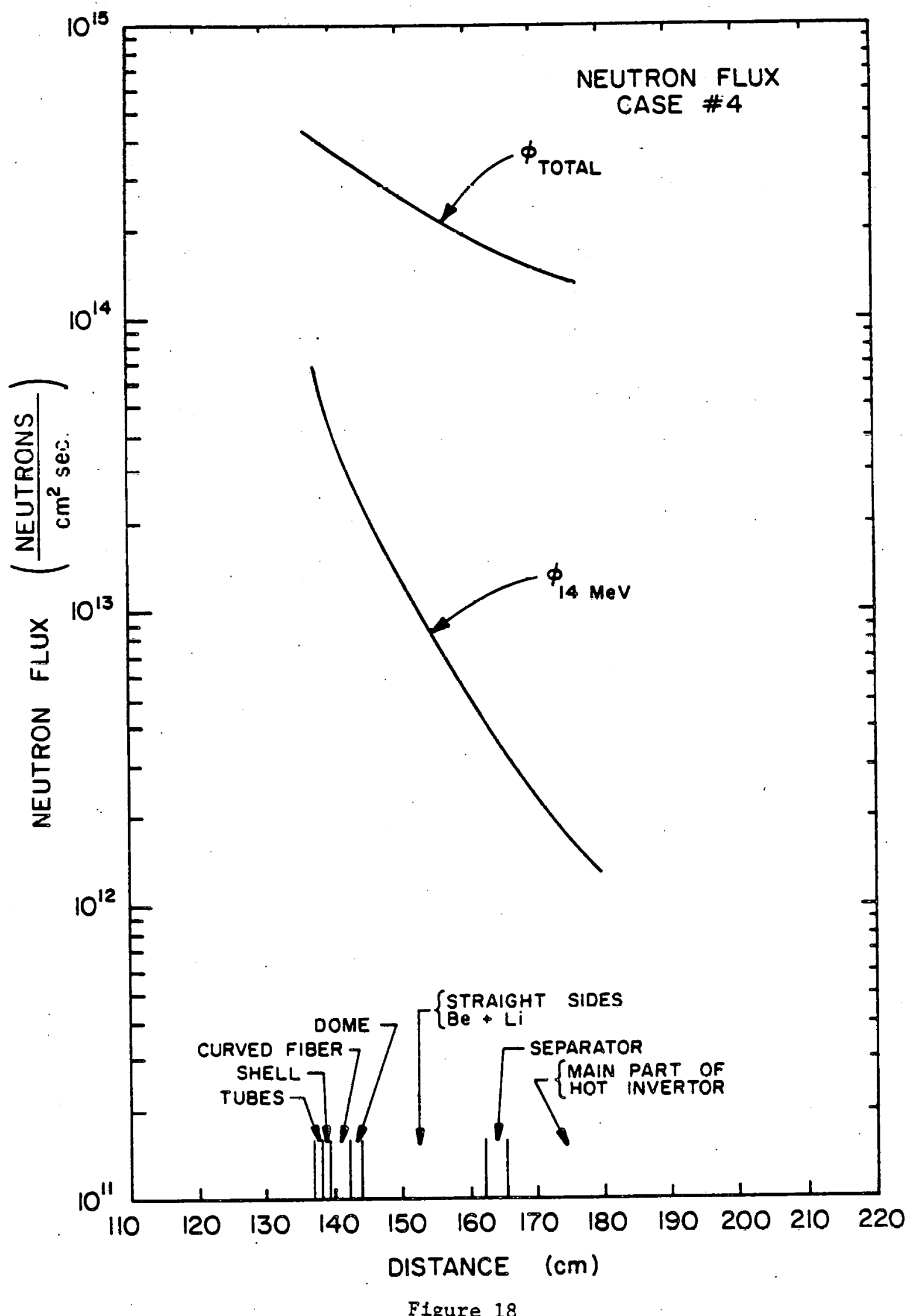




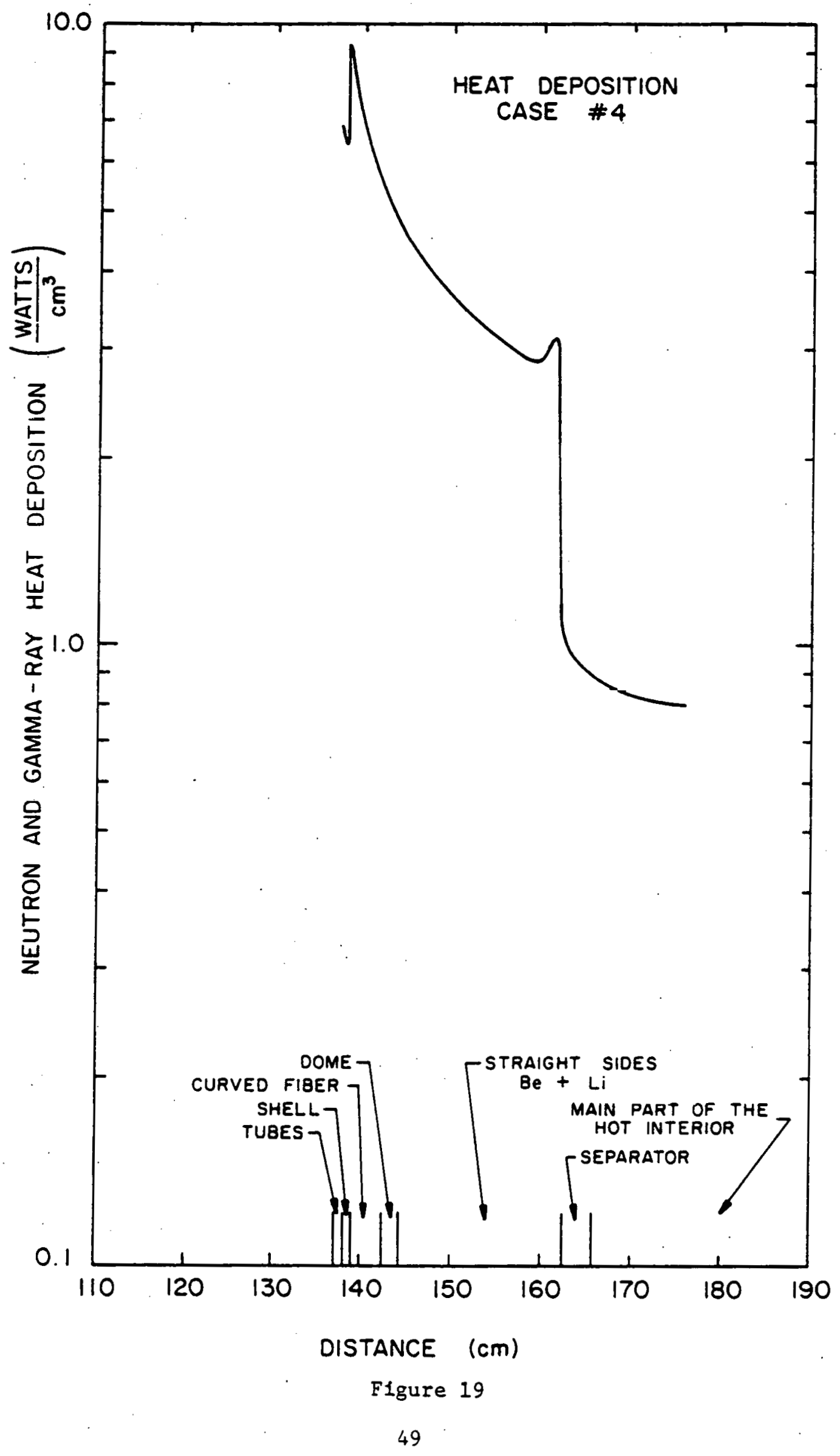




\section{CASE *5,1-ZONE \\ He-COOLED NO BREEDING}

\section{WALL FACE AS VIEWED}

\section{FROM PLASMA}

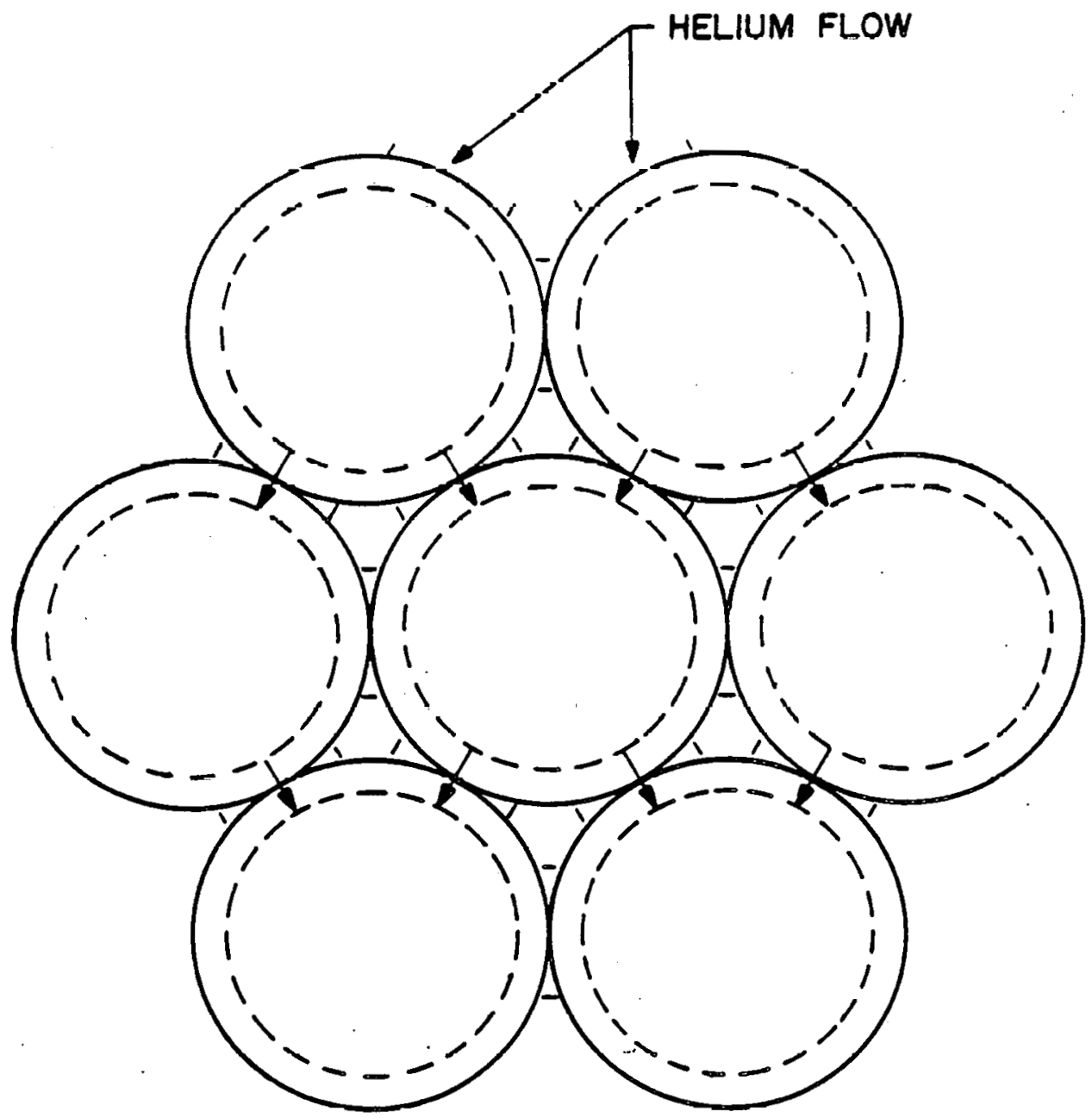

HELIUM OUTLET FLOW IS DOWN THROUGH CENTER OF EACH CYLINDER TO LOWER PLENUM

Figure 20 

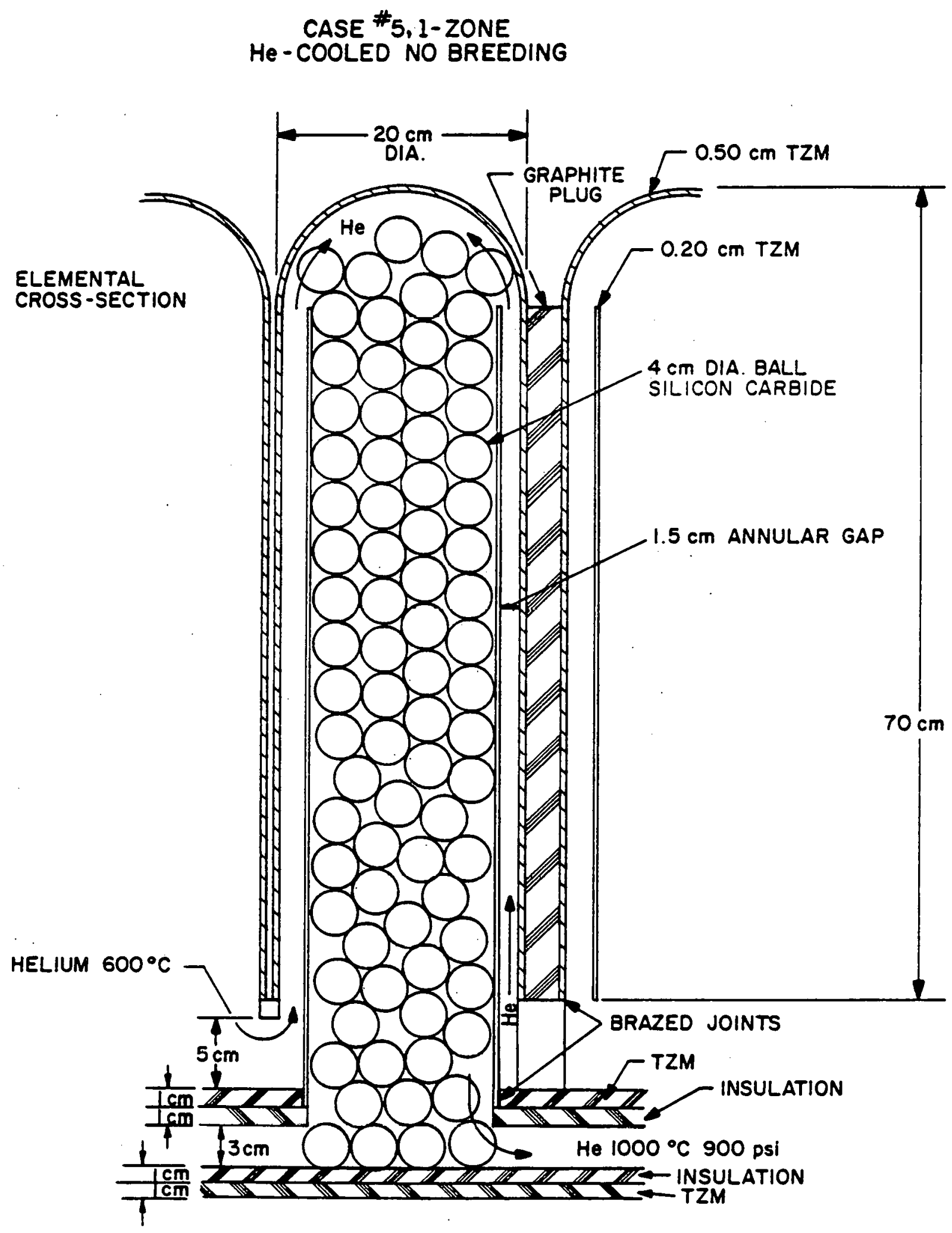

Figure 21 


\section{CASE \#6. 1 - ZONE \\ He-COOLED WITH BREEDING}

SEE CASE \#5 FOR

CONSTRUCTION DETAIL

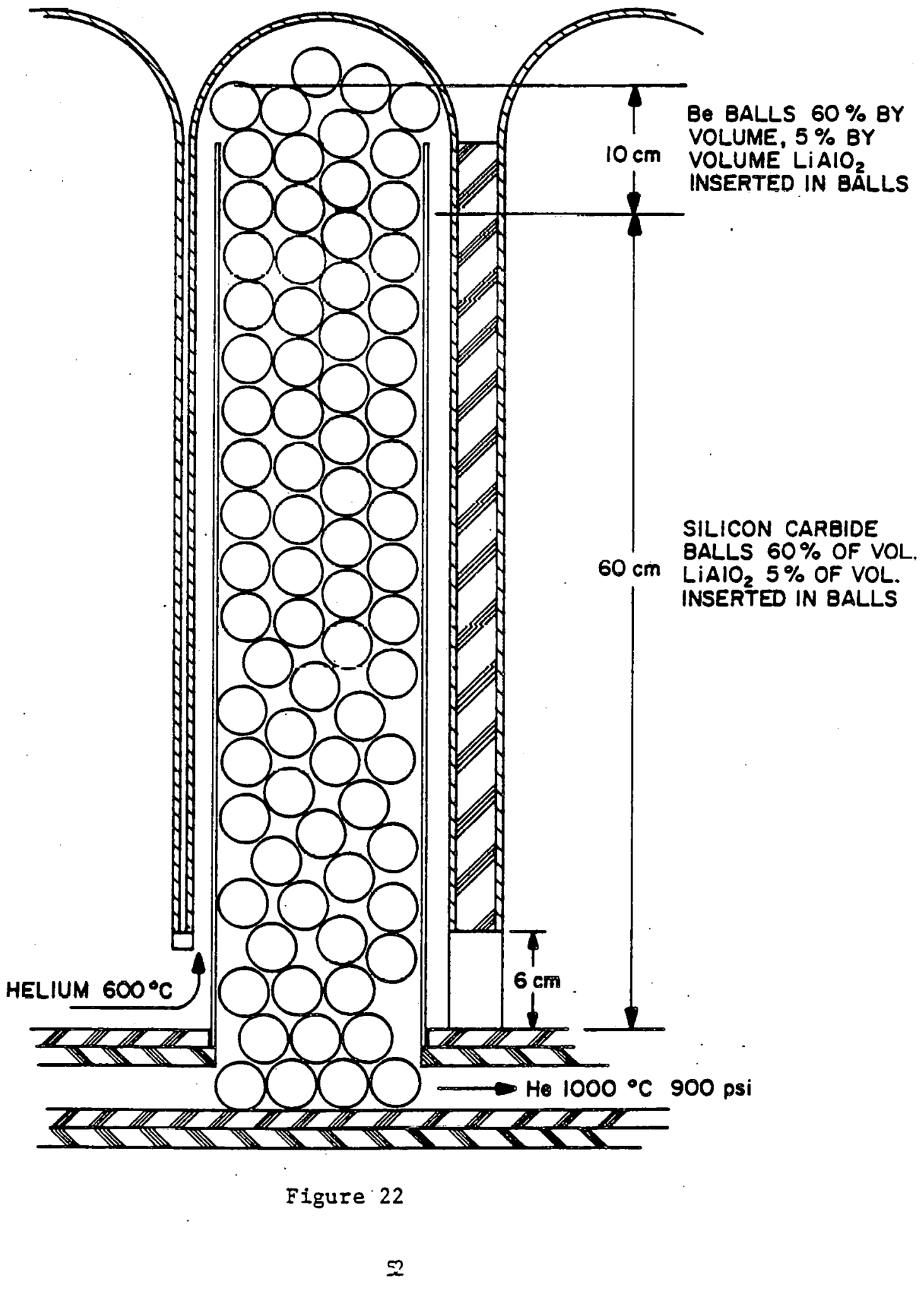


Table 18

\section{Blanket Type \# 5}

\section{Region}

Shell

Interior

Insulator

Backing Plate

Shield

Hot Interior Energy Fraction

Breeding Ratio
Material

TZM

( $\mathrm{He})$

Sic $(65 \%)$

(He)

$\mathrm{Al}_{2} \mathrm{O}_{3}(10 \%)$

$T Z M$

$\mathrm{B}_{4} \mathrm{C} \quad(80 \%)$

TZM (20\%)

$\mathrm{N} / \mathrm{A}$

None
Dimensions

$0.5 \mathrm{~cm}$ thick

$+0.2 \mathrm{~cm}$ thick interior shell

$4 \mathrm{~cm}$ dlam. balls

$80 \mathrm{~cm} \mathrm{high} \times 17 \mathrm{~cm}$ wide

$1 \mathrm{~cm}$ thick

2 separate regions

$15 \mathrm{~cm}$ thick

$100 \mathrm{~cm}$ thick 
Table 19

Blanket Type \# 6

Region

Shell

Breeding Zone

Hot Tnterior

Insulator
Material

TZM

(He)

Be $(60 \%)$

$\mathrm{LLAlO}_{2}$ (5\%)

(ile)

$\operatorname{SiC}(60 \%)$

$\mathrm{LiAlO}_{2}$ (5\%)

( $\mathrm{He})$

$\mathrm{Al}_{2} \mathrm{O}_{3}(10 \%)$
Dimensions

$0.5 \mathrm{~cm}$ thick

$+0.2 \mathrm{~cm}$ thick interior shell

$1 \mathrm{~cm}$ diam. ballg

$25 \mathrm{~cm}$ thick $\times 17 \mathrm{~cm}$ wide

4 cm dlam. balls
55 cm thick x 17 in wIde

$1 \mathrm{~cm}$ thick

2 separator regions

Backing Plate

Shield

(See Table 18)

Hot Interfor Energy Fraction

N/A

Breeding Rat10

0.68 


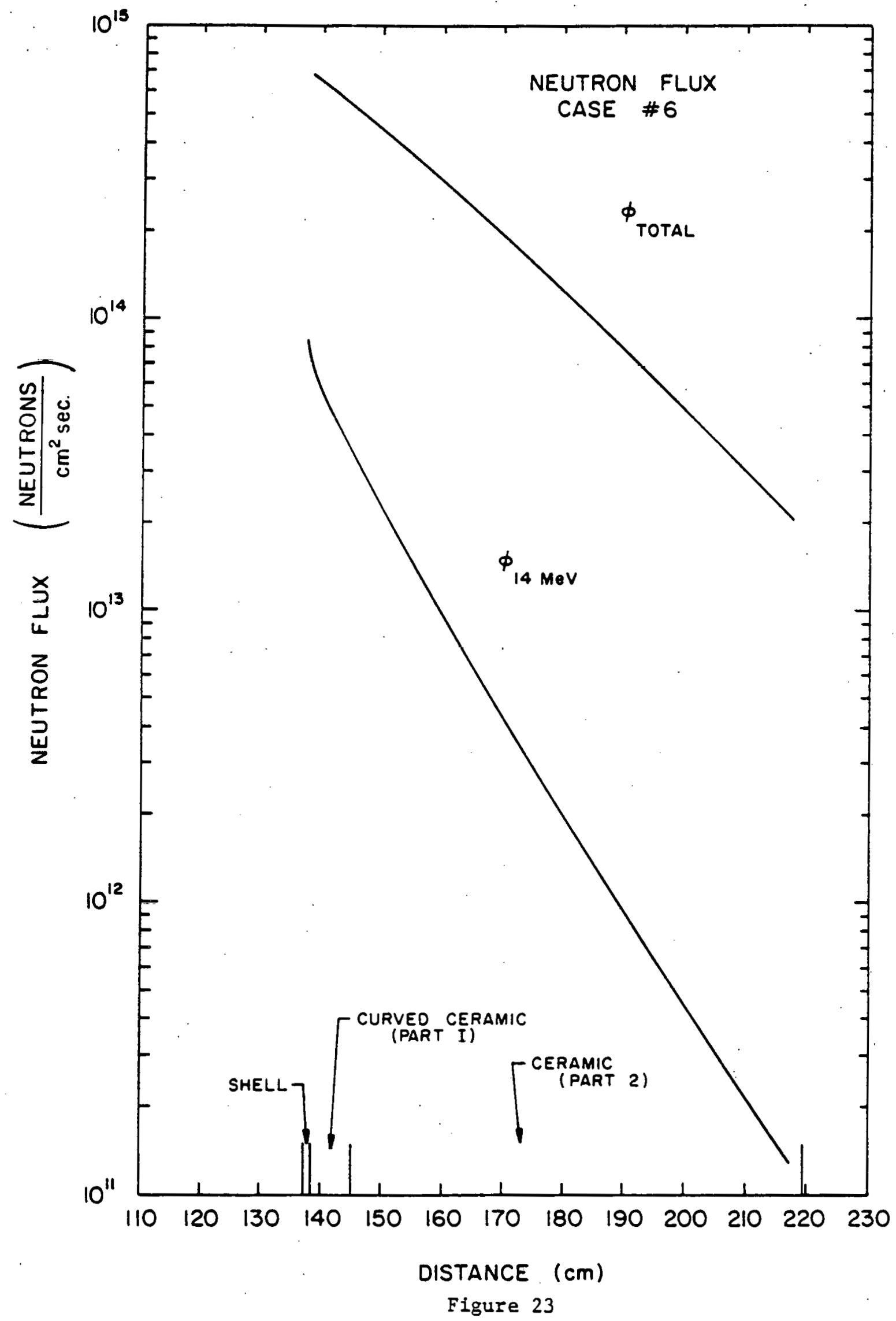


accordingly. It is unlikely that further increases in breeding ratio are readily obtainable.

The final group of blankets (types 7-10) utilizes both one and two-zone potassium cooled blankets as fllustrated in Flgures 24 and 25 . The thermally insulated hot interfor contains stagnant l1quid lithium or FLIBE in thin refractory metal tubes, held by an Inner metal shell. Alumina insulator is used between the hot interfor and the cooler shell, which is cooled by a set of attached coolent tubes carrying a two-phase mixture of potassium liquid and vapor. [The qualitỹ of the two-phase mixture is held relatively high (e.g., $\sim 0.7)$ so that the electrical resistivity of the mixture is much higher than that of the liquid metal. MHD pressure drops due to flow through the background magnetic field should be very small.] The interior is separately cooled by potassium vapor, which can be superheated to relatively high temperatures ( $1400^{\circ} \mathrm{C}$ ) depending on the materials compatibility. A vapor-1iquid separation operation on the two-phase coolant (outside the blanket) appears necessary with the separated vapor returned for superheat in the module interior.

Blanket types 7 and 8 are two-zone designs. These blankets resemble the one depicted in Figure 13 in that they are cylindrical rather than circular in design as are types 5 and 6. In type 7 (Table 20) TZM is the main structural material and is utilized to can $\mathrm{ZrC}$ in the hot interfor. In the breeding blanket type 8 (Table 21), TZM is used to can liquid LI or FLIBE in the hot interior. Figure 26 illustrates the neutron fluxes found for blanket type 8 . Again due to the lack of kerma factors for TZM, no heating profile is plotted. Due to the high neutron capture cross-section of molybdenum, it was necessary to optimize the design (decrease the amount of molybdenum) to raise the breeding ratio from .10 to .30 . In order to obtain heating profiles, a substitution of niobium for TZM in blanket type 8 was made (Table 21). Figures 27 and 28 depict neutron 


$$
\begin{aligned}
& \text { BLANKET \# } 7 \text { AND \#8 } \\
& 2-\text { ZONE } \\
& \text { K-COOLED ( } 2 \text { PHASE) }
\end{aligned}
$$

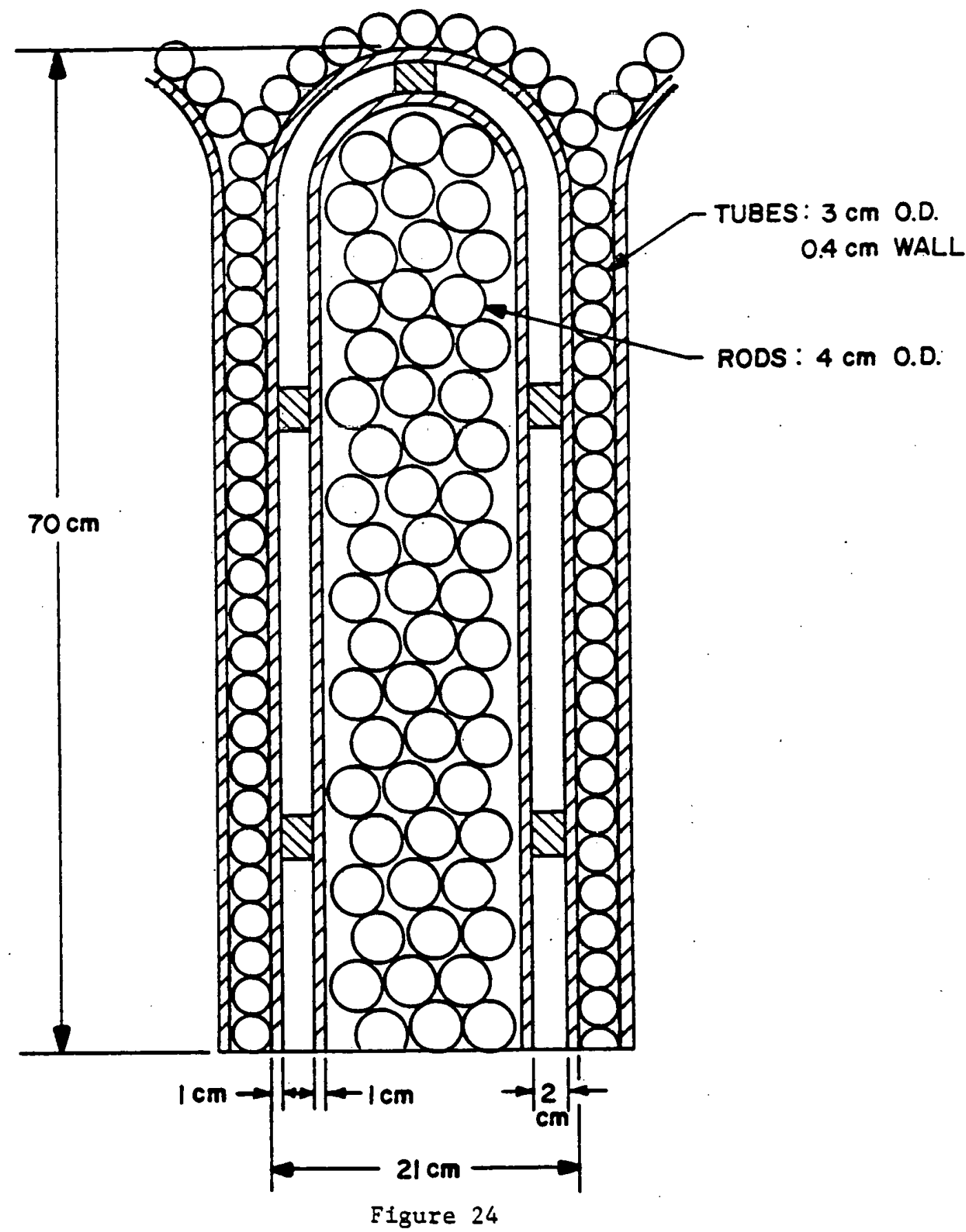




$$
\begin{aligned}
& \text { BLANKETS \#9 AND \#IO } \\
& \text { I-ZONE } \\
& \text { K-COOLED ( } 2 \text { PHASE) }
\end{aligned}
$$

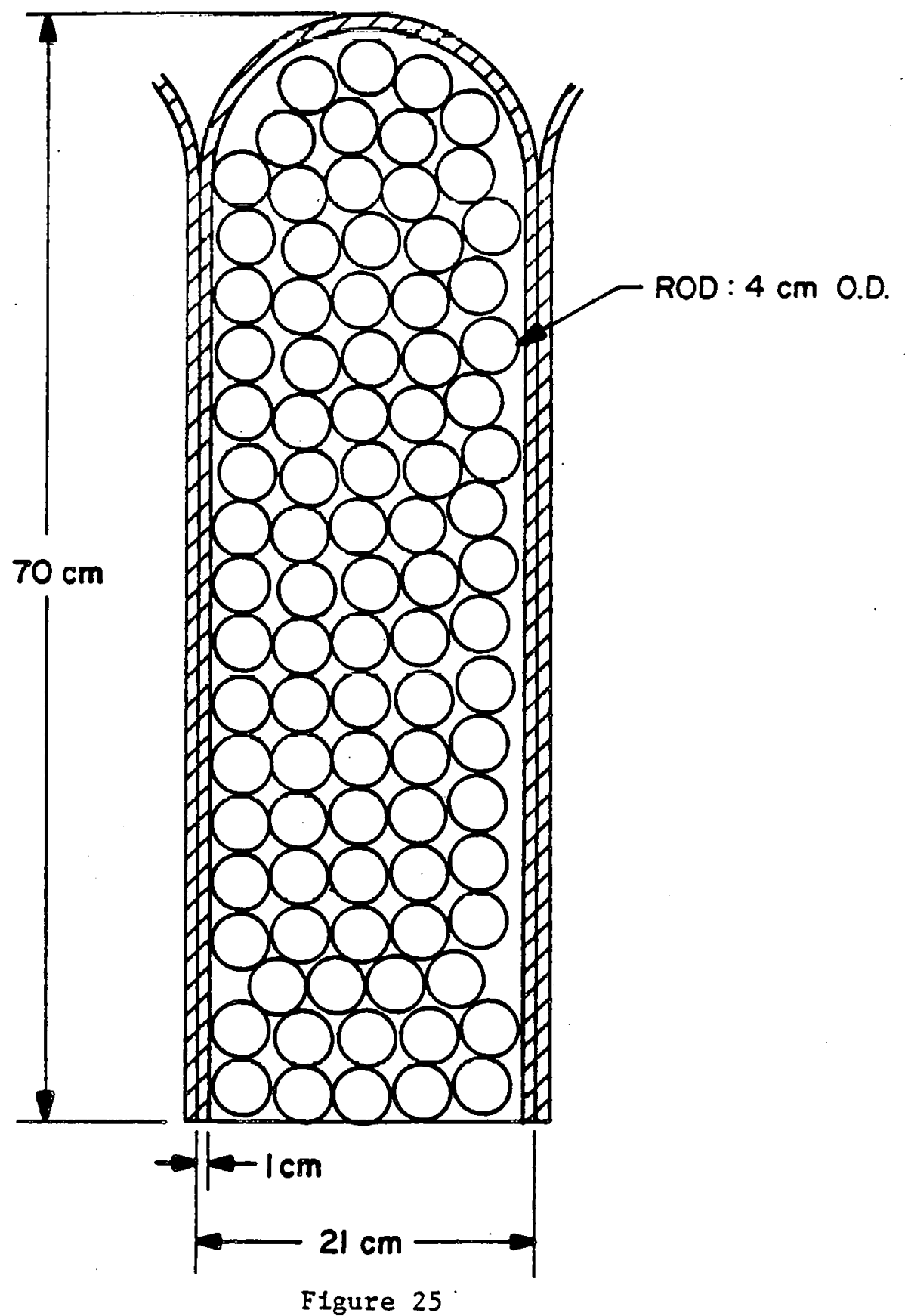


Table 20

\section{Blanket Type \# 7}

\section{Region}

Coolant Tubes

Shell

\section{Insulator}

Hot Interior

Backing Plate

Shield

Hot Interior Energy Fraction

Breeding Ratio

\section{Material}

TZM

$(K-2 \emptyset)$.

TZM

$$
\mathrm{Al}_{2} \mathrm{O}_{3} \quad(11 \%)
$$

$\operatorname{ZrC}(81 \%)$

$\operatorname{TZM}(9 \%)$

(K vapor)
(See Table 18)

N/A

None

\section{Dimensions}

$3 \mathrm{~cm} O D$

$.2 \mathrm{~cm}$ wall

$.3 \mathrm{~cm}$ thick

inside and outside shells

$2 \mathrm{~cm}$ thick

$4 \mathrm{~cm}$ OD rods TZM cans ZrC

$67 \mathrm{~cm}$ high $\times 16 \mathrm{~cm}$ wide 
Table 21

\section{Blanket Type \# 8}

Region

Coolant Tubes

Shell

Ineulator

Hot Interior

$\mathrm{Al}_{2} \mathrm{O}_{3}$ (11\%)

FLIBE (81\%)

TZM $(9 \%)$

(K vapor)

TZM

$(K-2 \emptyset)$

TZM

\section{Dimensions}

(See Table 18)

Shield

Backing Plate

Hot Interior Energy Fraction

N/A

Breeding Ratio

0.30

--Niobium instead of TZM---

Hot Interior Energy Fraction

Breeding Ratio

0.31 


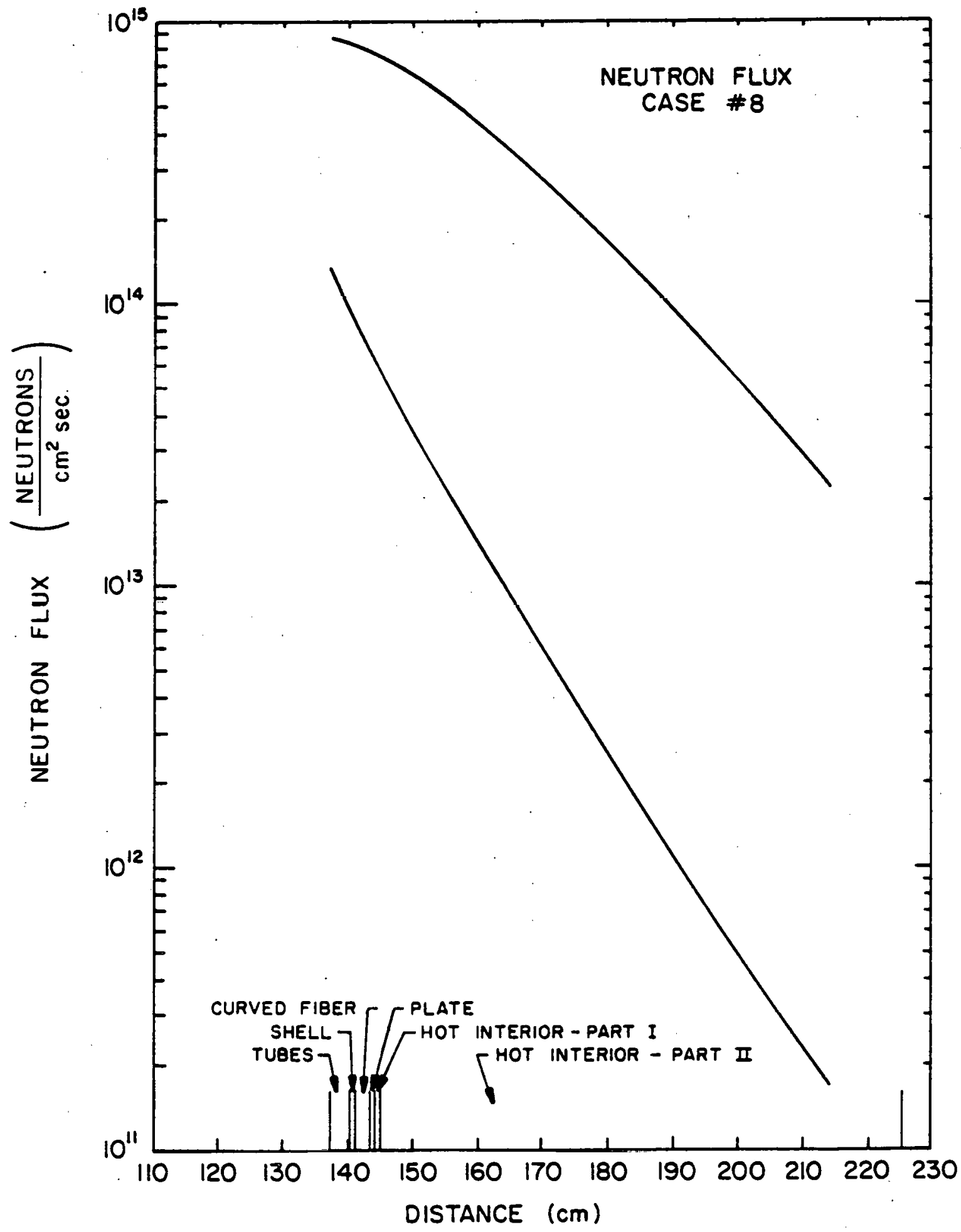

Figure 26 


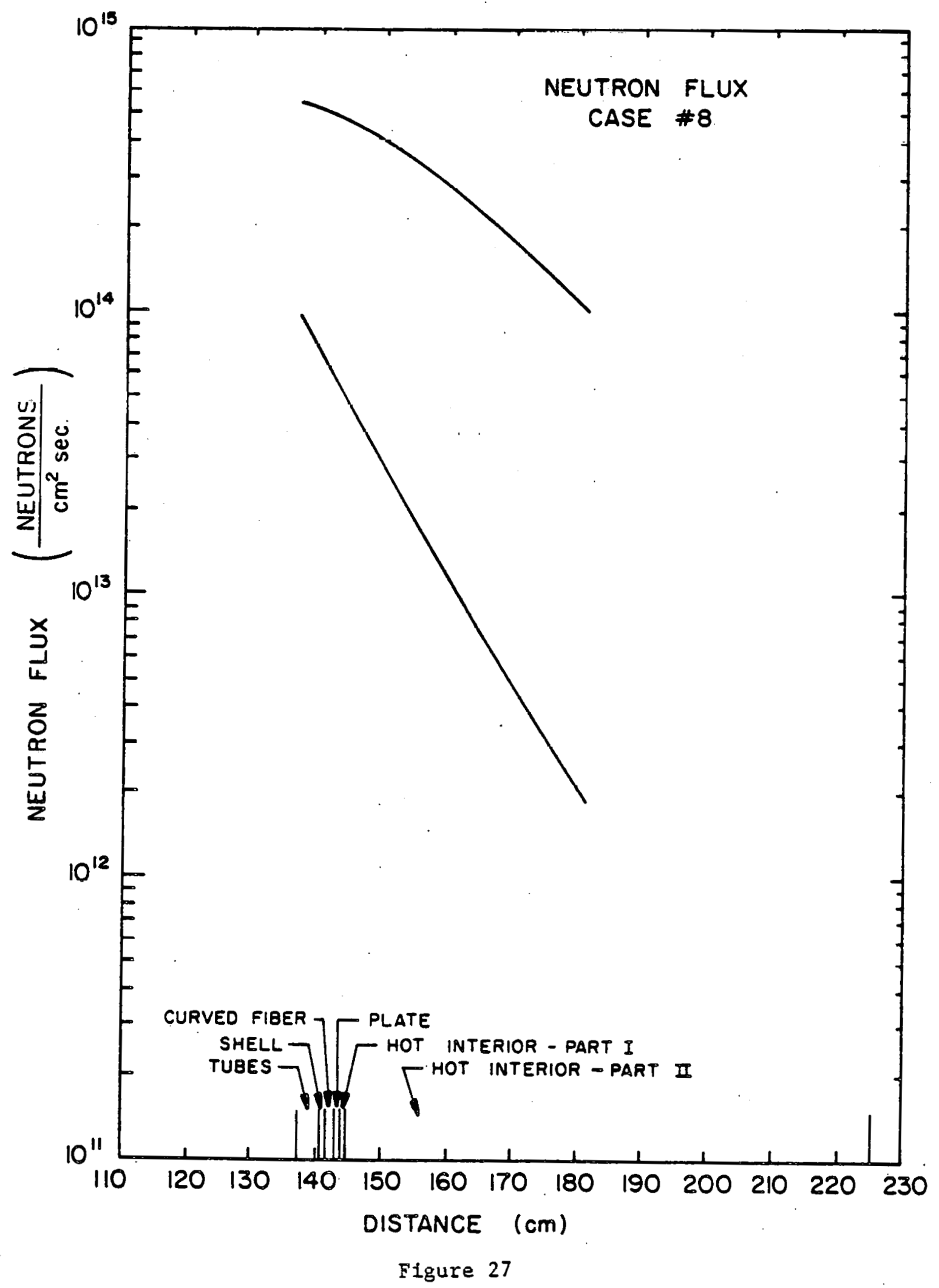




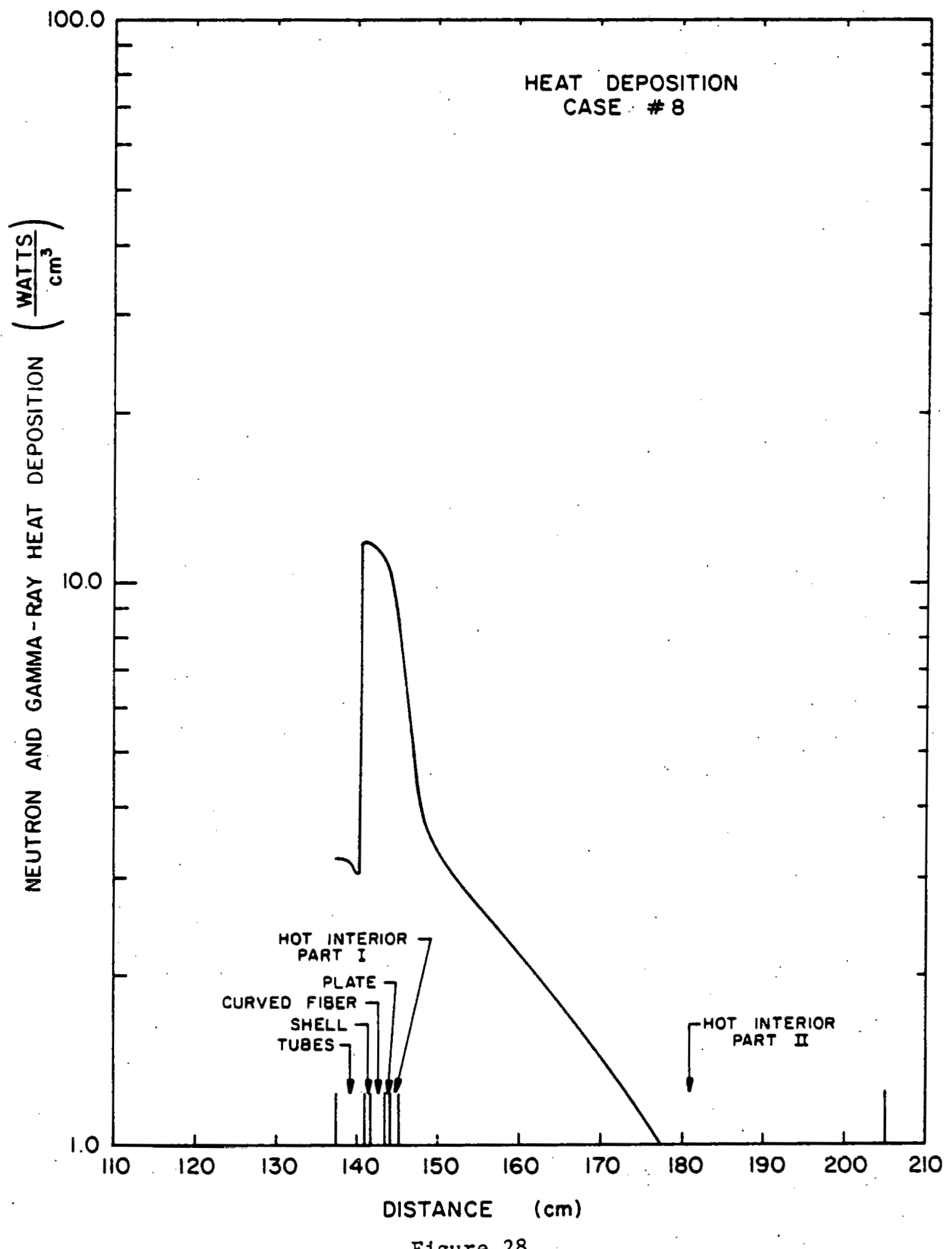

Figure 28 
fluxes and heating profiles for this material substitution. Although the breeding ratio was increased only to .31 , it was found that $48 \%$ of the energy was deposited in the high temperature intertor.

Blanket types 9 and 10 (Figure 25) as depteted in Tables 22 and 23 are one-zone designs cooled by two-phase potassium coolant. Figure 29 depicts. the neutron fluxes for blanket type 10. A breeding ratio of .17 was found for this blankst without any type of optimization of design. Decreasing TZM thicknesses could be expected to raise the breeding ratio as in the case of blanket \#8.

\section{CONCLUSIONS}

Basically, the blanket types examined all appear technically. viable, though the performance in some cases in not acceptable. The first group of blankets (types 1-4) do appear most promising. The analysis which was carried out and summarized in Tables 13 and 14 lead us to reach the following conclusion regarding blankets 1-4:

Combinations of design changes that significantly increase high temperature efficiency should result in a module design with high temperature efficiency approaching $70 \%$, even retaining the present material compositions (stainless steel, $\mathrm{SiC}, \mathrm{H}_{2} \mathrm{O}$, and $\left.\mathrm{He}\right)$. These would probably comprise a somewhat thinner insulation layer and a thicker/wider module. Higher values appear difficult to achieve, since alpha particle energy inherently limits efficiency to a value not much greater than $80 \%$ ( $Q$ values for these blankets are on the order of $20 \mathrm{MeV}$ ).

Neutronic analyses have also been carried out for the other blanket types. The general conclusions drawn from these studies indicate: 
Table 22

Blanket Type. 非 9

\section{$\underline{\text { Region }}$}

Shell

Interior
Material

TZM

$\operatorname{ZrC}(81 \%)$

TZM $(9 \%)$

$(\mathrm{K}-2 \emptyset)$
Dimensions

$0.5 \mathrm{~cm}$ thick

$4 \mathrm{~cm}$ OD rods TZM cans ZrC

$70 \mathrm{~cm}$ high $\times 20 \mathrm{~cm}$ wide

\section{Back1ng Plate}

Shield

$$
\text { (See Table 18) }
$$

Hot Interior Energy Fraction

N/A

Breeding Ratio

None 
Table 23

Blanket Type 10

\section{$\underline{\text { Region }}$}

Shell

Interior

Backing Plate

Shield

Hot Interior Energy Fraction

Breeding Ratio
Material

TZM

FLIBE (81\%)

TZM $(9 \%)$

$(K-2 \emptyset)$
(See Table 18)

N/A

.17
Dimensions

$0.5 \mathrm{~cm}$ thick

$4 \mathrm{~cm}$ OD rods TZM cans FLIBE

$70 \mathrm{~cm}$ high $\times 20 \mathrm{~cm}$ wid 


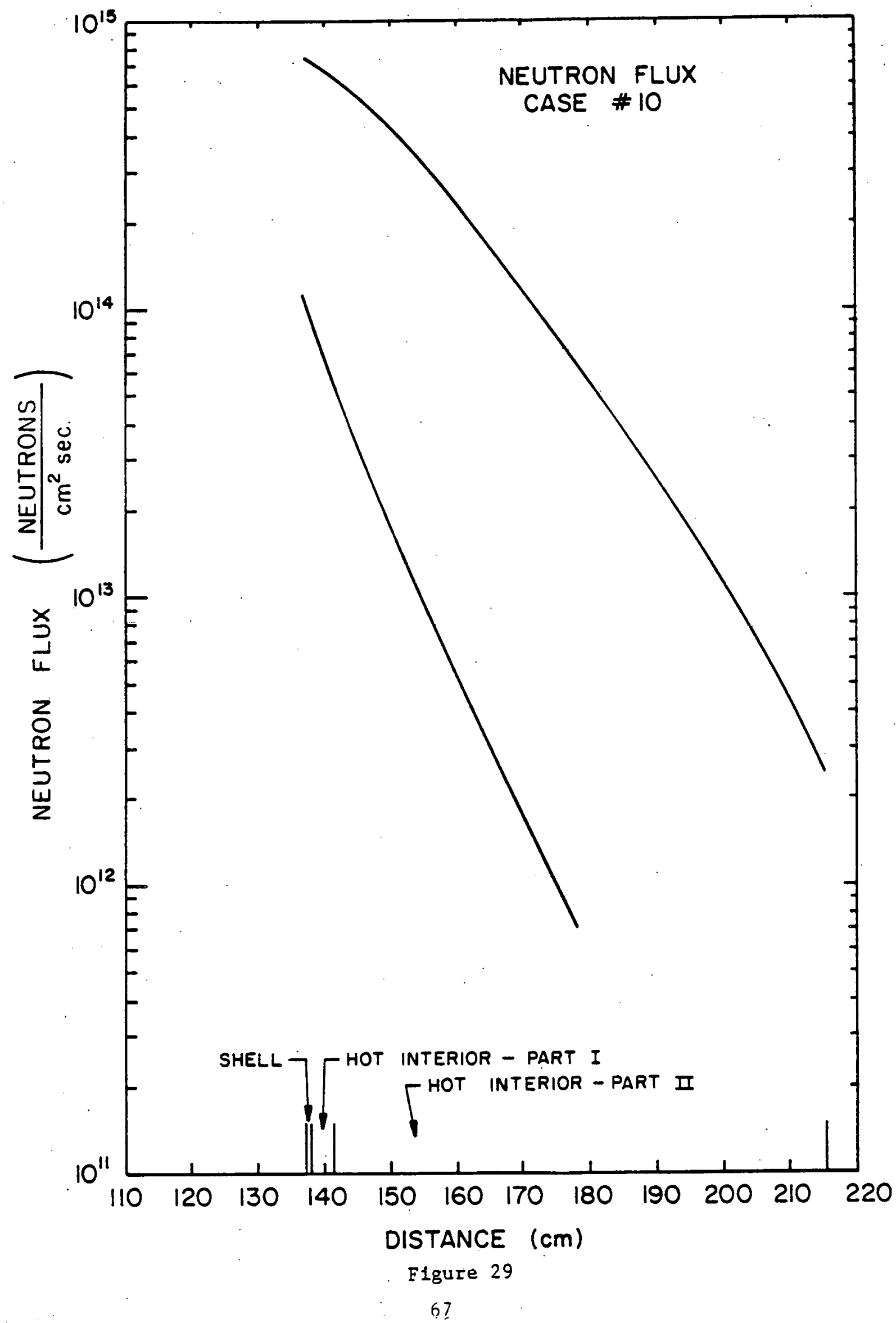


1. Two temperature zone blankets can be designed with a high (60-70\%) efficiency for deposition of fusion energy in the hot intertor.

2. Blankets with solid lithium compounds in the hot interfor (e.g., type \#2 blankets) can achieve tritium breeding ratios of $\sim 1.5$ if sulrable neutron multipliers (e.g., Be) are used.

3. The tritfum breeding ratios of the high temperature liquid lithium blankets (types \# 8 and 10) are well below one, because of the relatively large volume fraction of small diameter ( 4 cm OD) refractory metal tubes contalning the liquid lithium in the interior. This type of blanket rannot achieve a breeding ratio of onc unlcos the metal volume fraction is made much smaller, which would require impractically thin tubes or very large tubes.

4. The tritium breeding ratios of Blankets with breeding in the shell (by lithium containing fused salts) and steam cooled non-breeding interiors (type \#4) are relatively low ( 0.5 to 0.7 ) with most oxide refractories $\left(\mathrm{MgO}, \mathrm{Al}_{2} \mathrm{O}_{3}\right.$, etc.). If $\mathrm{BeO}$ is used in the intertor, however, breeding ratio. approaches one.

Thermal hydraulic analyses of the various blankets indicate that cooling should not be a problem in the interior of the blankets, since internal surface area is relatively high and volumetric power densitities relatively low at the wall loads considered, 1-2 $\mathrm{MW}(t h) / \mathrm{m}^{2}$. Substantial thermal gradients are anticlpated at the first wall, however, due to the high surface thermal flux resulting from low $Q$ operation. [The Infected power to maintain che plasma is assumed to reach. the first wall as x-rays (Bremsstrahlung) and kinetic energy of plasma lons and electrons]. Using 316 stainless steel tube walls for blankets 1 to 4, for example, the limiting temperature differences of $50^{\circ} \mathrm{C}$ in the tube wall are reached at wall loads of $1 \mathrm{MW}(\mathrm{th}) / \mathrm{m}^{2}$ and $Q=3$. Somewhat 
higher wall loads would be posstble with the more thermally conductive ferritic steels. With aluminum structure, temperature differences are quite small, and high wall loads $\left(\mathrm{e.g.,}, 3-4 \mathrm{MW}(\mathrm{th}) / \mathrm{m}^{2}\right)$, low $Q$ operation $(\mathrm{e} . \mathrm{g} ., \mathrm{Q} \sim 2$ ) appears practical.

Even if blankets can handle low $Q$ operation, however, the effect on power cycle efficiency will be very important, since the injected energy will be recovered from the lower temperature coolant circuit cooling the first wall (except in mirror type reactors, where it can be recovered in a direct converter). [It appears likely that the injected energy will have to go through a thermal cycle in tokamak reactors, because of the much lower plasma temperature and the difficulty of coupling a direct converter to a tokamak divertor.]

The above leads us to the overall conclusion that blanket type 1 represents the best alternative among the non-breeding blankets. The question of a breeding blanket remains somewhat open. A combination of blanket type 2 with a non-breeder appears to represent the most promising possibility at this time. Therefore, it is the blankets of the first group which comprise the basis of the detailed design study whlch initiates the second major phase of the analysis of fusion blankets for high efficiency power cycles. 
1. J. R. Powell, editor, "Preliminary Reference Design of a Fusion Reactor Blanket Exhibiting Very Low Residual Radioactivity", Brookhaven National Laboratory, BNL-19565 (December 1, 1974).

2. F. L. Horn, J.A. Fillo, J. R. Powell, "Performance of Ceramic Materials in High Temperature Steam and Hydrogen", Brookhaven National Laboratory BNL-25812, submitted to the First Topical Meeting on Fusion Reactor Materials, Mlami Beach, Florida, Log \# T5(90) (Jenuary 29-31, 1979).

3. R. Wiswall, E. Wirsing, and R. C. Hong, "The Removal of Bred Tritium from Solid Lithium Compounds in Fusion Reactor Systems", 14th InterSociety Energy Conversion Engineering Conference, Boston, MA (August $5-10,1979)$.

4. F. L. Horn, J. A. F1llo, J. R. Powell, "Performance of Insulating Materiais for Future Fusion Blankels", Brookhaven National Iahnratory. BNL-26883, submitted to 16th International Thermal Conductivity Conference, Clicago, IL (November 7=9, 1979).

5. W. W. Engle, "A User's Manual for ANISN", K-1963, Union Carbide Corp., Nuclear Division, Oak Ridge Gaseous Diffusion Plant, Oak Ridge, TN

6. RSIC Data Library Collection, DLC-37 D, "EPR-Coupled 100-Group Neutron 21 Group Gamma Ray Cross Sectlons for EPR Neutronics".

7. 0. W. Lazareth, J. S. K. Tsang, and J. R. Powell, "Two-Dimensional Heating Analysis by Computer Simulation of a Fusion Reactor Synfuel Blanket Module in a Neutron Beam," BNL-26355, Presented at 1979 ANS Winter Meeting, San Francisco, California (November 11-16, 1979).

8. K. D. Lathrop and F. W. Brinkely, "TWOTRAN-II: An Interfaced, Exportable Version of the TWOTRAN Code for Two-Dimensional Transport", LA-4848 MS, Los Alamos Seicntific Laboratory, Los Alamos, New Mexico. 